\title{
mRNA Transcript Abundance during Plant Growth and the Influence of $\mathrm{Li}^{+}$Exposure
}

M.C. Duff ${ }^{1} *$, W.W. Kuhne ${ }^{1}$, N.V. Halverson ${ }^{1}$, C-S. Chang ${ }^{2}$, E. Kitamura ${ }^{2}$, L. Hawthorn ${ }^{2}$, N.E. Martinez ${ }^{1,3}$, C. Stafford $^{1,4}$, C.E. Milliken ${ }^{1}$, E.F. Caldwell ${ }^{1}$, and E. Stieve-Caldwell ${ }^{1}$

${ }^{1}$ Savannah River National Laboratory, Aiken, SC 29808.

${ }^{2}$ Integrated Genomics Core, Georgia Regents University Cancer Center, Augusta, GA 30912.

${ }^{3}$ Dept. Env. and Radiological Health Sciences, Colorado State University, Ft. Collins, CO 80523.

${ }^{4}$ University of South Carolina Medical School, Columbia, SC 29208.

*Corresponding Author:

Dr. Martine C. Duff, Savannah River National Laboratory, Aiken SC 29808

Phone: 803-725-2054

Email: Martine.Duff@srnl.doe.gov

Keywords: Arabidopsis thaliana, microarray, Next Generation Sequencing, lithium exposure, hydroponics, soil

(C) 2014. This manuscript version is made available under the Elsevier user license

http://www.elsevier.com/open-access/userlicense/1.0/ 


\begin{abstract}
Lithium $(\mathrm{Li})$ toxicity in plants is, at a minimum, a function of $\mathrm{Li}^{+}$concentration, exposure time, species and growth conditions. Most plant studies with $\mathrm{Li}^{+}$focus on short-term acute exposures. This study examines shortand long-term effects of $\mathrm{Li}^{+}$exposure in Arabidopsis with $\mathrm{Li}^{+}$uptake studies and measured shoot mRNA transcript abundance levels in treated and control plants. Stress, pathogen-response and arabinogalactan protein genes were typically more up-regulated in older (chronic, low level) $\mathrm{Li}^{+}$-treatment plants and in the much younger plants from acute high-level exposures. The gene regulation behavior of high-level $\mathrm{Li}^{+}$resembled prior studies due to its influence on: inositol synthesis, 1-aminocyclopropane-1-carboxylate synthases and membrane ion transport. In contrast, chronically-exposed plants had gene regulation responses that were indicative of pathogen, cold, and heavy-metal stress, cell wall degradation, ethylene production, signal transduction, and calcium-release modulation. Acute $\mathrm{Li}^{+}$exposure phenocopies magnesium-deficiency symptoms and is associated with elevated expression of stress response genes that could lead to consumption of metabolic and transcriptional energy reserves and the dedication of more resources to cell development. In contrast, chronic $\mathrm{Li}^{+}$exposure increases expression signal transduction genes. The identification of new $\mathrm{Li}^{+}$-sensitive genes and a gene-based "response plan" for acute and chronic $\mathrm{Li}^{+}$exposure are delineated.
\end{abstract}




\section{Introduction}

Lithium (Li) is a naturally abundant element in the earth's crust and it is found in relatively concentrated forms in igneous rocks, continental, oilfield, and geothermal brines, hectorite (aluminosilicate) clays, and ocean water. Chile is the major Li producer followed by Argentina, China, the US, and Russia [1]. It is used in ceramics, batteries, pharmaceuticals, and high energy propellants and for the production of tritium. As the uses for Li expand, environmental contamination from production and disposition processes becomes more important to monitor. Significant waste sources are the large-scale disposal of Li batteries, mining effluents and sludges [2] as well as $\mathrm{Li}$ isotopic separations facilities [3].

Within biological systems, $\mathrm{Li}$ is considered a non-essential nutrient although there is some evidence that it may be essential [4]. Lithium-depleted diets will alter reproductive success in rats and goats [5-10]. Lithium is used in the medical field to treat bipolar disorder and related mental diseases such as depression and schizoaffective disorder. It may have potential in the prophylaxis of Alzheimer's disease [11]. Several mechanisms have been proposed for its action. Although research continues, the mechanism for how Li helps treat mental illnesses remains unknown [4]. High levels of Li cause signs of toxicity in patients [9], may be teratogenic in the early developmental stages $[12,13]$ but $\mathrm{Li}$ is not mutagenic nor does it cause chromosomal damage (breaking) [2]. Lithium normally occurs in freshwater at levels below $0.04 \mathrm{ppm}(\sim 0.006 \mathrm{mM})$ as reviewed by Kszos and Stewart [3] although some natural waters can have higher levels. For plants, when Li-rich waters are used for irrigation, adverse effects on crops have been observed which negatively impact the agricultural industry $[10,14]$.

Lithium ions can modify biochemical processes through direct interaction with proteins and through the modification of gene expression in plants. The most thoroughly-described example in the literature is the mechanism by which $\mathrm{Li}^{+}$interacts with the inositol triphosphate second messenger system. The $\mathrm{Li}$ ion is an uncompetitive, rapid, and reversible inhibitor of myo-inositol-1-phosphatase (IMP or IMPase), an enzyme involved in a rate-limiting step of inositol second messenger recycling and the hydrolysis of myo-inositol phosphate. The $\mathrm{Li}^{+}$reduces the rate of hydrolysis of myo-inositol-1-phosphate without altering the binding of the substrate or the essential magnesium ion $\left(\mathrm{Mg}^{2+}\right)$ to IMPase according to research studies with animal systems [15]. For patients with mood disorders that have elevated levels of brain myo-inositol and respond to Li treatment, $\mathrm{Li}^{+}$may inhibit myo-inositol hydrolysis but $\mathrm{Li}^{+}$may exert a therapeutic influence by acting on secondary signaling pathways, such as that of protein kinase $\mathrm{C}$ [16]. In plants, $\mathrm{Li}^{+}$has been shown to inhibit IMPase but no verification that the plant uses a non-competitive mechanism has been conducted on a purified plant enzyme. Recently conducted nuclear magnetic resonance (NMR) studies with bovine IMPase [17] and binding site modeling studies [18] that calculated Gibbs free energy values for $\mathrm{Mg}^{2+}$ and $\mathrm{Li}^{+}$binding sites on various IMPases and glycogen synthase kinase $3 \beta(\mathrm{GSK}-3 \beta)$ reveal that $\mathrm{Li}^{+}$can compete with $\mathrm{Mg}^{2+}$ when certain conditions permit its physical accessibility to these proteins. Similar observations have been made by Srinivasan et al. [19] with guanine-nucleotide binding proteins (G-proteins). It should be noted that $\mathrm{Li}^{+}$competition with $\mathrm{Mg}^{2+}$ is not thought to be universal with all proteins [18]. Lithium ion is unable to compete with $\mathrm{Mg}^{2+}$ for binding sites with other cell-essential mammalian proteins (that are unassociated with bipolar disorder) because those proteins do not have binding sites that are accessible to $\mathrm{Li}^{+}$. The formation of inositol by IMPase from myoinositol-1-phosphate drives a release of intracellular calcium $\left(\mathrm{Ca}^{2+}\right)$ from the endoplasmic reticulum (ER), which serves as a signal for many mammalian cellular processes [20] but this has not been shown in plants. In addition to effects on enzyme activity, $\mathrm{Li}^{+}$also modifies mRNA expression of IMPase in plants [21-23]. In yeast exposed to $0.2 \mathrm{mM} \mathrm{Li}^{+}, \mathrm{Li}^{+}$causes the inhibition of mitochondrial RNA processing endoribonuclease as observed by Dichtl et al. [24].

Lithium also has variable effects on the 1-aminocyclopropane-1-carboxylate synthase (ACC synthase) family proteins as noted by Liang et al. [25]. ACC synthase catalyzes the synthesis of ACC, a precursor for ethylene, from $S$-adenosyl methionine (SAM). This reaction is a rate-limiting step for the synthesis of the important plant hormone, ethylene. Lithium modifies mRNA expression of SAM [26-28] and an array of other 
proteins including the potentially important pathogenesis-related (PR) protein family [29, 30]. Finally, $\mathrm{LiCl}$ solutions are occasionally used in the place of $\mathrm{NaCl}$ solutions in plant salinity studies. Although $\mathrm{LiCl}$ can provide control over the ionic strength of the solution there may be specific ion effects of $\mathrm{Li}^{+}$that do not emulate that of $\mathrm{Na}^{+}$. The specific ion effect of $\mathrm{Li}^{+}$on plant enzyme activity and gene expression is relevant to the biochemical and molecular processes in cells and it may improve the understanding of $\mathrm{Li}^{+}$effects in mammals as well as plants.

Since there is a growing interest in investigating differences in plants at both the phenotypic and genomic levels under native conditions (i.e., in soil) [31] we utilized both growing platforms, hydroponic solutions (HP) and soil. In this paper we discuss the effect of control and $\mathrm{Li}^{+}$-exposed $(0.05$ to $1 \mathrm{mM} \mathrm{LiCl})$ plants that were grown in soil (as mainly chronic $\mathrm{Li}^{+}$-exposure) and in $\mathrm{HP}$ solution (for acute $\mathrm{Li}^{+}$-exposure) in relation to their controls. We measured the Li content of plant shoots from our HP studies to determine how rapid $\mathrm{Li}^{+}$uptake could occur and analyzed the transcriptome of the controls and the $\mathrm{Li}^{+}$-exposed plants. We discuss the gene regulation for shoot tissue from soil-grown plants over a 5-wk period in the controls and discuss the impact of chronic low-level $\mathrm{Li}^{+}$on the gene regulation. We also report on the effects of acute $\mathrm{Li}^{+}$exposure in $\mathrm{HP}$ studies and how that compares and contrasts to the long-term effects of chronic low-level $\mathrm{Li}^{+}$exposure.

\section{MATERIALS AND METHODS}

Arabidopsis thaliana seeds of the Columbia (Col-0) wild type (Lehle Seeds, Inc., Round Rock, TX) were sterilized by soaking in sterilization solution [22.1 mL deionized water (DI), 95\% ethanol (EtOH), $500 \mu \mathrm{L}$ Triton ${ }^{\mathrm{TM}}$ X-100 (Sigma-Aldrich, St. Louis, MO)] for 5 min. followed by an immediate rinsing with $95 \% \mathrm{EtOH}$. Once the $95 \% \mathrm{EtOH}$ had evaporated and the seeds were dried they were kept at $4{ }^{\circ} \mathrm{C}$ for $3 \mathrm{~d}$. Seeds were then exposed to a red light for $30 \mathrm{~min}$. to synchronize germination.

\subsection{Hydroponic Growth of At}

On average five seeds were placed onto a rockwool plug (Grodan 1.5" Miniblocks ${ }^{\mathrm{TM}}$, Netherlands) that had been pre-soaked in HP media [0.14 $\mathrm{g} \mathrm{L}^{-1} 1 / 32$ Murashige and Skoog Basal Salt Mixture or "MS salt" (SigmaAldrich, St. Louis, MO), with $0.25 \mathrm{~g} \mathrm{~L}^{-1}$ MES hydrate (Sigma-Aldrich) in DI water, $\mathrm{pH}$ balanced to 5.7 with potassium hydroxide in a HP growth tray]. HP growth trays are Pyrex glass containers $(2.6 \mathrm{~L})$ that were covered with aluminum foil and covered with a dark blue lid. For seeding and germination purposes a lid with 46 holes for holding individual rockwool plugs was used. Plugs were pre-soaked in HP media. Trays were initially covered with a perforated plastic wrap to promote germination and eliminate condensation buildup and maintained in growth chambers (Percival Scientific, Inc., Model AR66L3C8, Perry, IA) under conditions of $9 \mathrm{~h}$ light: $15 \mathrm{~h}$ dark, 22 to $25^{\circ} \mathrm{C}, 50 \%$ humidity and light intensity of $250 \mu$ moles $\mathrm{m}^{-2} \mathrm{~s}^{-1}$ at a shelf height of $0.3 \mathrm{~m}$. Seeds were germinated and kept in HP media for $14 \mathrm{~d}$ at which time the plastic wrap was removed and an airline added. Plants were maintained until d 21 at which time the plants were culled to one plant per plug and roots had fully emerged from the rockwool but were not becoming entangled with one another. At $24 \mathrm{~d}$ (in age), the plants were moved to a new glass tray containing two glass replicate boats with the roots from eight plants emerged in $300 \mathrm{~mL}$ of HP media within each boat. A new lid design was used to accommodate two additional airlines per boat. Plants at $26 \mathrm{~d}$ of age were then exposed to LiCl- or NaCl-spiked HP media as well as control HP media solutions (Table 1). Plants were exposed to $1 \mathrm{mM} \mathrm{LiCl}, 1 \mathrm{mM} \mathrm{NaCl}$ or the control HP media for periods of 1 or $7 \mathrm{~d}$. The plants were exposed hydroponically, via their roots which were submerged in the treatment solutions.

\subsection{Lithium Uptake Studies with HP Plants}

Kinetic uptake studies were conducted in duplicate with HP-grown, 46-day old At plants that were exposed to a concentration of $0.1 \mathrm{mM} \mathrm{LiCl}$ for periods of up to 1 to $96 \mathrm{~h}$. The tissues were placed into paper bags and dried in an oven for $12 \mathrm{~h}$ at $50^{\circ} \mathrm{C}$. Samples were then ground into a fine powder using liquid nitrogen $\left(\mathrm{N}_{2}\right)$ 
with porcelain mortar and pestle and dried for an additional $48 \mathrm{~h}$ at $50^{\circ} \mathrm{C}$. Lithium levels in the nitric aciddigested plants and HP test solution were determined quantitatively using inductively coupled plasma mass spectrometry (ICP-MS). A minimum of $0.5 \mathrm{~g}$ (dry weight or $\mathrm{dw}$ or $35 \mathrm{~g}$ wet weight) plant material was required for ICP-MS which was conducted in duplicate.

\subsection{Soil-based Growth of At}

Seeds were sown in large grow pots (Kordlok SQL0450, with 4:1 Promix PGX (Premier Horticulture, Quebec, Canada): Hoffman Horticultural Perlite (Good Earth, Lancaster, NY)). Prior to seeding, the pots were soaked in DI water for at least $3 \mathrm{~d}$ to pre-moisten soil for planting. Seeds were sown as 3 sets of 5 seeds per pot. Pots were kept at ambient temperature under short $\mathrm{d}$ light cycles of $9 \mathrm{~h}$ light: $15 \mathrm{~h}$ dark. Plants were allowed to grow for $14 \mathrm{~d}$ at which time plants were culled to only 3 plants per pot (1 plant per section). Plants received 25 $\mathrm{mL}$ of $1 / 64 \mathrm{HP}$ media to each quadrant of the pot (100 mL total volume) every 3 to $4 \mathrm{~d}$.

\subsection{Collection and Processing of At Tissue for RNA Analysis}

Using sterile conditions to limit RNAse contamination, shoot tissues were collected from each plant. A total of $150 \mathrm{mg}$ of fresh weight biomass was harvested for each replicate sample, flash frozen in liquid $\mathrm{N}_{2}$, ground to a fine powder using a porcelain mortar and pestle, and kept at $-80^{\circ} \mathrm{C}$ until RNA extraction. Total RNA was extracted from shoot samples with the RNeasy Plant Mini Kit (Qiagen Inc., Valencia, CA). Extractions were conducted following the manufacturer's instructions and the quality and quantity of the extracted RNA was checked with the NanoDrop 2000C Spectrophotometer (Thermo Scientific ${ }^{\circ}$, Waltham, MA) and the Agilent Bioanalyzer 2100 (Agilent Technol., Inc., Santa Clara, CA). Only RNA that passed a defined series of quality control metrics (e.g., having a NanoDrop 260/280 ratio >1.8 and RIN or RNA Integrity Number on the bioanalyzer >7) were analyzed with Next Generation Sequencing (NGS) using a HiSeq 2500 (Illumina Inc., San Diego, CA).

\subsection{RNA Analysis}

For the microarray (MA) analyses, Affymetrix GeneChips® (Affymetrix, Santa Clara, CA) were used according to the Affymetrix Expression Analysis Technical Manual for the Arabidopsis Genome ATH1 Array. Prior to the NGS, cDNA libraries were constructed of the Total RNA using TruSeq RNA Sample Prep. v.2 kits (Illumina). The libraries were checked for appropriate quantities and qualities of cDNA using a Qubit巴 2.0 (Invitrogen $^{\mathrm{TM}}$, Grand Island, NY) or qPCR (StepOnePlus, Applied Biosystems, Grand Island, NY) and an Agilent Bioanalyzer 2100. All MA and NGS samples were run in triplicate.

The NGS data were de-multiplexed using CASAVA 1.8.2 software by aligning reads to the Arabidopsis genome (TAIR 10) using TopHat 2.0.4. Runs were set as 50 cycle paired-end reads. Sequences were compared to three publically-available At databases: 1) NCBI Arabidopsis thaliana TAIR10, 2)

Illumina/igenome.database/refgene.gtf, and 3) TAIR (http://www.arabidopsis.org/gene). The differential expression of the transcripts was determined using Cuffdiff/Cufflink 2.0.0 software. The software was used to detect raw mapped reads, normalize the data to "fragments per kilobase per million mapped reads" and compare the differential expression of the treatments versus the controls.

For the MA data, differentially-regulated genes were identified by ranking the fold-change (in log base 2, also referred to as " $\log 2$ ") to a specific "cut-off" value at $p$-value of 0.05 (Student's $t$-test). The MA chips and that MA data are subject to problems as discussed by [32]. Therefore, the MA data were constricted to a conservative fold-change value of \pm 1.5 whereas the NGS data, which are more robust, quantitative and qualitative, were not restricted to a fold-change value. A recent review of NGS technique and data analysis which is used widely in this report can be obtained from Van Verk et al. [33]. For the NGS data from the soil study, the amount of data was massive and for simplification, the discussion was often limited to the top 100 most abundant 
transcripts that met the $p$-value cut-off and were up- or down-regulated. In some cases, all of the identified genes that met the $p$-value cut-off in the soil study were discussed as noted.

\section{RESULTS AND DISCUSSION}

\subsection{Phenotypic Observations and Uptake Behavior in Li $i^{+}$-exposed HP Plants}

The HP plants that were exposed to $1 \mathrm{mM} \mathrm{LiCl}$ for 7-d exhibited chlorosis and shriveling, which were most evident in the older leaves (see image of 7-d exposure plants in Fig. 1). Root tissues in the HP plants that were exposed to $\mathrm{Li}^{+}$for $7 \mathrm{~d}$ were severely compromised and much of the root tissue biomass was lost relative to the controls. In contrast, phenotypic symptoms of plant stress in the 1-d $\mathrm{HP}$ exposure (with $1 \mathrm{mM} \mathrm{NaCl}$ or $\mathrm{LiCl}$ ) and all of the soil treatments were not visible. Figure 2 shows that the uptake of $0.1 \mathrm{mM} \mathrm{Li}^{+}$from $\mathrm{HP}$ media by A. thaliana shoots is rapid. The exposed plants are most likely undergoing processes to cope with the $\mathrm{Li}^{+}$influx, which involves gene expression changes.

Lithium sensitivity is plant species dependent; however, the level of $\mathrm{Li}^{+}(0.05 \mathrm{mM}$, which equates to $0.347 \mathrm{ppm} \mathrm{Li}$ ) that was used in the soil-based study was high enough to induce minor injury to some agricultural crops. Concentrations as high as $0.07 \mathrm{mM} \mathrm{Li}^{+}$are tolerated by some plants like irrigated corn as described by Bingham et al. [10]. Higher levels of $\mathrm{Li}^{+}(12 \mathrm{ppm})$ produce chlorosis, leaf tip necrosis, interveinal necrosis and abnormal leaf development after a 7-d exposure with some symptoms being marginally-evident as early as $1 \mathrm{~d}$ for Phaseolus vulgaris (snap bean) plants that were treated with 8.0 and $12 \mathrm{ppm} \mathrm{Li}^{+}$[34]. Other studies performed by our laboratory $[35,36]$ have shown that upon 3 wks of exposure to $15 \mathrm{mM} \mathrm{LiCl}$, soil-grown At leaves also experience chlorosis. But the chlorosis is most pronounced in the oldest leaves, which is somewhat evident after $1 \mathrm{wk}$ of $1.0 \mathrm{mM} \mathrm{LiCl}$ exposure in HP-grown plants as in Fig. 1. This type of behavior is consistent with classic $\mathrm{Mg}^{2+}$ deficiency as described by [37] Taiz and Zeiger (2010) who note that $\mathrm{Mg}^{2+}$ deficiency in plants can influence the behavior of enzymes that are involved in photosynthesis, respiration, as well as RNA and DNA synthesis. Interveinal yellowing in the leaves was evident in these other studies, which is also consistent with the delayed effect of $\mathrm{Mg}^{2+}$ deficiency on the chlorophyll in the vascular bundles. Some interveinal yellowing is apparent in Fig. 1 as well. Additional studies were recently performed by our laboratory $[35,36]$ with near IR reflectance measurements and quantification of extracted chlorophyll $\mathrm{a}+\mathrm{b}(\mathrm{Chl} \mathrm{a}+\mathrm{b})$ levels of the At leaves in soilgrown plants treated with $15 \mathrm{mM} \mathrm{LiCl}$. Upon 3 wks of exposure, At leaves produced vegetation indices (specifically the SIPI or structural independent pigment index) which were inversely-correlated with measured $\mathrm{Chl} \mathrm{a}+\mathrm{b}$ levels and with RWC (relative water content) indices. Low values of the SIPI and RWC indices were observed in plants that were exposed to $\mathrm{Li}^{+}$for long periods of time (3 wks, relative to controls).

\subsection{Analysis of Entire Genome in the Control Plants from the Multiweek Soil Studies}

Analysis of the total RNA collected from plants over the 5 wks based on the cDNA fragments sequenced and mapped back to the genome show that the younger plants in wks 1, 2 and 3 had the highest numbers of genes that met the cut-off requirements $(2463,3006$, and 3213 respectively). Older plants in wks 4 and 5 showed a decrease in the number of identified genes (622 and 744 respectively) but they had higher abundance levels of the identified transcripts.

The TAIR GO Functional Analysis search engine [38] was used to determine biological function of genes

present by wk (Table 2). The levels of genes associated with cell organization and biogenesis (10.2\%), developmental processes (8.2\%), and electron transport or energy pathways (4.1\%) dominated at wk 1 . As the plants aged, the genes associated with above mentioned biological functions were reduced in number. Genes associated with the biological functions of response to abiotic or biotic stimulus (31.4\%), response to stress $(32.3 \%)$, signal transduction (17.8\%), and transport (21.0\%) showed inverse responses with the lowest values being observed in younger plants (wks 1 and 2) and they increased to their maximum values by wk 5 . 
For the GO functional categories of other cellular processes and other metabolic processes the levels for all five wks averaged $\sim 49.0 \%$ respectively just under the $\sim 56$ and $53 \%$ reported for the whole genome. The elevated levels of stress response genes in wks 4 and 5 could potentially be explained at least in part by the experimental design. The plants were sown 3 per pot for statistical replication and biomass purposes. Daily observation of these plants revealed no obvious signs of fungal disease, pest/insect infestation or discoloration of leaves. While no obvious signs of stress were present, the plants at 4 and 5 wks were quite large and could have been crowded or dehydrated. These conditions could be reflected in the genomic response, although these conditions are also likely to exist in nature - particularly as the plant prepares for senescence and seed production at the end of its growing cycle.

\subsection{Analysis of the 100 Most Abundant Genes by Wk from the Control Plant in the Soil Studies}

Analysis of the top 100 most abundant genes by wk showed that in comparison, the overall trend in gene expression was that of down-regulation in the control plants. In wks 1 and 2,36\% of the genes were up-regulated and related to photosynthesis processes (specifically, At1g23130, At1g51402, At1g74470, At3g14420, At4g32260, At5g38410, CA2, CA3, CAB2, DRT112, ESM1, FED A, GAPA, GGT1, LHCA1, LHCB2.1, LHCB2.2, LHCB3, LHCB4.2, LHCB6, PRK, PSAD-1, PSAD-2, PSAE-1, PSAG, PSAH2, PSAK, PSAN, PSAO, PSBQA, PSBTN, PSBW, PSBX, PSBY, RCA, TRX3). In tissues from wks 2 to 3, only $7 \%$ of genes were upregulated and they were related to unknown functions, translation, dehydration response, lateral root development and cellular protein modification (At2g25510, At5g42530, At5g54940, ERD14, RGF9, and UBQ11).

Control plant shoot tissues from wks 3 to 4 showed up-regulation of 15 out of the top 100 genes. Investigation of the function of these genes revealed that they were associated with root hair elongation (At4g05150 and BAL1) and response to other organisms (At1g75800). These genes could be associated with the fact that plants were crowded and in search of water although this may be a normal progression of plants that are ending their lifecycle. Other genes up-regulated from wk 3 to 4 show increased activity related to the gibberellic acid signaling pathway (At1g74670, XTH24), xyloglucan degradation (EXGT-A3) which has been described as an important step prior to cell death in aging leaves [39], and defense response (At1g75800 and At2g30930). From wks 4 to 5 the only up-regulated gene was At2g41090, which is associated with $\mathrm{Ca}^{2+}$-binding, response to mechanical stimulus, and phosphate starvation. By wk 5 (relative to wk 4), there were 61 up-regulated genes (Table 3) relative to wk 4 in the top 100 most abundant genes for the control plants. Of these 2 were unknown, 36 genes are associated with pathogenesis-related response or defense response genes and 6 associated with programmed cell death or leaf senescence.

A wk to wk comparison of the top 100 most abundant genes in the control plants shows that only 5 genes were found in at least four of the wks observed: At1g72430, At1g74670, At2g15960, BGAL1 and CCL. In wks 1 to 2, the following genes were down-regulated: At1g12440, At2g23120, At3g15450, At3g61260, At3g63160, At4g05150, At4g27280, At5g10860, At5g57655, ASN1, BGAL1, CCL, COR15A, DYL1, GASA1, KIN2, STP1, TCH4, and XTH4, which are associated with developmental processes and stress/defense response. Many of these genes were also down-regulated by wk 3. See Table 4 for gene descriptions and direction of gene regulation.

When results from wks 3 and 4 were compared, there were several up-regulated genes for stress/defense response (At1g72430, At1g74670, At3g48740, At4g05150, At4g05150, CCL and ELP). Those genes that became downregulated by wk 4 were primarily associated with growth and cellular differentiation (At3g63160, KIN2) and defense response (ACS6, AOC1, At1g32920, At1g72910, At1g74450, At2g30020, At2g43530, At3g22235, At3g28220, At5g02160, AOC2, BIP1, COR15A, DIC2, ERF104, GSTF6, GSTF7, PCC1, RAV2, PRXCB, and PORB). In wks 4 to 5, many of the 100 most abundant genes were associated with defense/stress/pathogenesisrelated response. Genes that were down-regulated in wk 4 but trending upward at wk 5 were: AGP12, 
At1g22190, At1g23710, At1g32928, At3g57450, At1g18740, At3g19030, At3g46620, At4g27652, At4g27657, At4g29780, At5g22250, CML38, IAA7, NUDT21, NUDT4, ORA47, PUP18, TCH2, TGG1, TGG2, UCP5 and WRKY40. See Table 4 for more information.

\subsection{Numbers of Unique Genes by Wk from the Control Plants in the Soil Studies}

The numbers of unique genes that were identified between plants of different ages varied with the youngest plants showing the largest numbers (i.e., 1559) and the older plants at wks 3 through 5 had ten-fold less gene diversity. The biological functions of the unique genes revealed that younger plants in wk 1 were often representative of cell organization and biogenesis and developmental processes, as well as electron transport or energy pathways. Plants in wk 2 showed no unique genes as compared to wks 1 and 3 . The older plants in wks 3 , 4 and 5 showed decreases in the number of genes that were associated with cell organization and biogenesis and developmental processes, but there were increases in genes associated with DNA/RNA metabolism, protein metabolism, and response to abiotic or biotic stimulus or stress.

\subsection{Gene Comparisons with $\mathrm{Li}^{+}$-treated Plants in the Soil Studies}

The $\mathrm{Li}^{+}$-treated plants from wks 1,2 and 3 had the largest numbers of identified genes that met the cutoff: 2748,2753 and 2824 as compared to the older $\mathrm{Li}^{+}$-treated plants in wks 4 and 5 with 936 respectively. Unlike the control plants where there were also fewer genes identified in the later wks, the $\mathrm{Li}^{+}$-treated plants from later time periods had lower overall transcript abundances with the exception of several genes that function in stress defense and signaling (to be discussed) by wk 5-see Table 5 for more information.

Use of the TAIR GO Functional annotation search engine with gene ID data for $\mathrm{Li}^{+}$-treated plants from wks 1 and 2 revealed genes that were mainly associated with cell organization and biogenesis and developmental processes. By wk 3, the plants had greater DNA and RNA metabolism as well as protein metabolism. Additionally those genes that were associated with response to abiotic and biotic stimulus, as well as general stress response genes, began to increase in number. By wks 4 and 5, those genes that were associated with DNA or RNA metabolism or protein metabolism had decreased while the stress response genes remained elevated. Those numbers of genes that were associated with signal transduction and transport also reached a maximum level during these final wks, in terms of their contribution to biological function.

\subsection{Review of the Top 100 Most Abundant Genes by Wk for the Soil-grown Li ${ }^{+}$-treated Plants}

A review of the top 100 genes by transcript abundance revealed that only 56 genes were found in more than two of the sampled wks. According to the TAIR GO Biological Function search engine, these 56 genes were primarily associated with developmental processes, other biological processes, response to abiotic or biotic stimulus, response to stress, signal transduction and transport (Table 6 and Supplementary Table A).

The number of genes within the top 100 most abundant for the $\mathrm{Li}^{+}$-treated plants that were found only in a single two consecutive-wk comparison was 86 for wks 1 vs 2,80 for wks 2 vs 3 and 82 for wks 3 vs. 4 . The biological functions of these unique genes by wk revealed that in wks 4 and 5 the plants had increased biological function for cell organization and biogenesis and developmental process, along with electron transport and energy pathways, transport, response to abiotic and biotic stress, and signal transduction (Supplementary Table B).

\subsection{Comparison of Treatment vs. Control on Gene Response in Soil-grown Plants}

When all of the genes from wks 1 to 5 were input for the determination of GO biological functions in TAIR, the genes that represented cell organization and biogenesis, developmental processes, protein metabolism and transport were more elevated in the $\mathrm{Li}^{+}$-treated plants relative to that of the controls (Supplementary Table C). 
Slightly lower values were measured in the $\mathrm{Li}^{+}$-treated plants relative to the controls for response to abiotic or biotic stimulus, response to stress, signal transduction and transport.

However, the top 100 most abundant genes in $\mathrm{Li}^{+}$-treated plants were associated with developmental processes, response to abiotic or biotic stimulus, and response to stress, signal transduction and transport (Supplementary Table C). Signal transduction increased with time while transport behaviors started high, decreased in wks 3 and 4 and increased towards initial values by wk 5.

In the $\mathrm{Li}^{+}$-treated plants, several genes were measured in wks 4 and 5 that are commonly associated with the cold response pathway: CCL, COR15A COR15B, COR413IM1, DELTA-TIP, IAA7, KIN2, LTI78 and TCH4 (Table 6). Several of the COR genes also encode a Late Embryogenesis Abundant or "LEA" proteins as described by [40]. Many of these genes are also associated with drought or salt stress because they are responsive to cell dehydration. Additionally many of the cold response changes can respond to hydrogen peroxide formation. Treatment of plants with hydrogen peroxide has been shown to mimic cold acclimation [41, 42]. Cold response is also linked to circadian rhythms [43].

Knight et al. [44] used a transgenic 7-d Arabidopsis seedling to investigate cold $\mathrm{Ca}^{2+}$ signaling. Under normal conditions cold shock elicits an immediate rise in cytosolic free $\mathrm{Ca}^{2+}$ concentrations. This change in $\mathrm{Ca}^{2+}$ levels has been reported to be a necessary step in a temperature-sensing mechanism that enables the plant to withstand future cold stress better. Proteins enhanced by the cold-induced genes KIN1 and KIN2 may act as "antifreeze" for plants because they have a similar sequence to those found in fish. KIN2 is also associated with salt stress and drought/dehydration stress. Dehydration of cells is common to cold events.

In summary, of the up-regulated genes within the top 100 most abundant genes, those genes in the early wks of exposure (wks 1 vs 2) genes were associated mainly with cell organization and biogenesis, developmental processes, electron transport and energy pathways. This is consistent with normal growth and a requisite production of biomass of plants of this age and much like that in the controls. There were also several genes associated with protein metabolism, other metabolic processes and the stress response and response to abiotic and biotic stimulus genes.

In the later wks, wks 3 to 4 and 4 to 5 , there was a change in the genome profile. The genes that were associated with cell organization and biogenesis remained similar in total number to the early wks ( 1 vs 2 ), while genes that were associated with electron transport and energy pathways and development became less abundant with time. By wks 3, 4 and 5, there was an increase in genes associated with response to abiotic and biotic stress, response to stress, signaling, transcription-DNA dependent, and transport.

Some but clearly not all of the identified genes and their expression behaviors that were observed in our study were unprecedented. These genes and their gene regulation responses are presented in several of the following examples and in Tables 7 through 11 unless noted otherwise.

\subsection{Inositol Monophosphate Gene Family Transcript Abundance Behavior in the HP vs. Soil Studies}

In the HP 1-d and 7-d LiCl exposures, several genes that were related to the inositol synthesis and the phosphatidylinositol signaling pathway were differentially-expressed relative to the control and to equimolar $\mathrm{NaCl}$. These included, but were not limited to, those that are listed in Table 7. The calculated fold-changes for the plant shoots from the HP studies are listed in Table 8. In the $\mathrm{HP} \mathrm{Li}^{+}$-treated plants, the MIPS2 gene was upregulated after $\mathrm{d} 1$ but by $\mathrm{d}$ 7, the MIPS1, MIPS2, the putative MIPS and inositol monophosphate genes were down-regulated. The putative trypsin inhibitor (TI1) was up-regulated in the $\mathrm{Li}^{+}$-treated plants from the are involved with phosphatidyl-inositol phosphorylation, ER stress, and systemic acquired resistance) in the $\mathrm{Li}^{+}$exposed plants were up-regulated in the HP studies (Table 7). Some of these genes to a lesser extent were observed at the end of the soil-based studies but the level of up-regulation was not as pronounced. 


\subsection{ACC Synthase Protein Gene Abundance Behavior in the HP vs. Soil Studies}

The genes that are associated with 1-aminocyclopropane-1-carboxylate (Table 7) were typically downregulated in the HP studies and they were not differentially-regulated and identified at the statistical cut-off in the soil studies (at a $p$-value of $\leq 0.05$ ). High levels of auxin help to stimulate ACC synthase, which his induced by stress and it controls ethylene biosynthesis [47].

\subsection{Pathogenesis-related (PR) Protein Gene Abundance Behavior in the HP vs. Soil Studies}

The plant shoots that were exposed to $1 \mathrm{mM} \mathrm{LiCl}$ in the 7-d HP tests demonstrated up-regulation of the PR proteins. These proteins were PR1, PR2 and putative PR genes (as discussed previously and as listed in previous tables). These genes had fold-change values $(p<0.05)$ from +4.16 to +6.36 for $\mathrm{Li}^{+}$-treatment relative to the control for the 7-d exposures (Table 8). PR1 and another PR protein putative (At4g31470) were up-regulated when the gene expression of $\mathrm{Li}^{+}$-exposure relative to $\mathrm{Na}^{+}$-exposure was compared with fold-change values of +3.06 and +1.91 respectively. At4g10500 (an oxidoreductase) that is a predicted functional partner protein of PR1 was up-regulated as well in the HP studies. The 1- and 7-d $1 \mathrm{mM} \mathrm{NaCl} \mathrm{HP}$ treatments did not exhibit the upregulation response, suggesting that $\mathrm{Li}^{+}$has some unique effects on the transcriptome response. Predicted functional partners as found with STRING [45] revealed that PR1 is closely associated with other PR-type gene proteins. PR1 as well as PR5 are co-associated with the allergen V5/Tpx-1 f.p. (At5g66590, data not shown) and the PR protein putative (At4g25780), which were both down-regulated in the 7-d LiCl HP treatments (Table 8). Again, these proteins were not highly expressed the $1 \mathrm{mM} \mathrm{NaCl} \mathrm{HP}$ treatments, suggesting that this is a $\mathrm{Li}^{+}-$ induced specific ion response as opposed to a $\mathrm{Na}^{+}-$or $\mathrm{Cl}^{-}$-induced response.

In the soil studies (see specific genes as listed in Table 11) several wks of watering with $0.05 \mathrm{mM} \mathrm{LiCl}$ enhanced the up-regulation of the PR genes relative to that of the control. These included PR1 and PR5 which were in the top 20 most abundant transcripts at wk 5 of the $\mathrm{Li}^{+}$-treatment series. Another identified gene which has a predicted functional partner of PR1 is BGL2 (beta-1,3-glucanase 2), which was up-regulated and the second most abundant transcript in the wk $5 \mathrm{LiCl}$ treatments. Other transcripts that code for other predicted functional partner proteins and were in the top 100 most abundant transcripts for the $\mathrm{Li}^{+}$-treatments at wk 5 were: At4g10500, LURP1 (late up-regulated in response to Haloperonospora parasitica), and SAG13 (At2g29350, alcohol dehydrogenase/oxidoreductase; senescence-associated gene). All of these high abundance genes were upregulated relative to the control. None of these genes were expressed relative to the $1 \mathrm{mM} \mathrm{Na}{ }^{+}$or $0 \mathrm{mM}$ control in the HP studies.

In tobacco plants, treatment with high levels of $\mathrm{Li}^{+}$caused phenotypic responses (necrotic lesions, leaf curling), accumulation of ethylene, salicyclic acid, and gentisic acid and it induced the expression of the PR genes: PR-P, PR1, and PR5 [29]. With the exception of PR1, $\mathrm{Li}^{+}$produced the same effects in transgenic tobacco plants that do not accumulate salicylate due to an overexpression of $n a h G$ (the bacterial hydroxylase gene). Inhibition of ethylene biosynthesis with aminoethoxyvinylglycine (AVG) in these studies precluded any $\mathrm{Li}^{+}-$ induced cell death and PR5 expression. This suggests that $\mathrm{Li}^{+}$engages a hypersensitive plant response where ethylene production and enhanced signaling occur in the acute $\mathrm{Li}^{+}$exposures as well as the chronic, low-level $\mathrm{Li}^{+}$ exposures.

\subsection{Arabinogalactan Protein (AGP) Family Gene Abundance in HP}

In the HP and the soil studies, the exposure of $\mathrm{Li}^{+}$produced up-regulation of the AGP family gene. Table 6 lists several of the AGP genes from the soil studies. AGP2, AGP5, AGP10, and AGP24 were all up-regulated in the 7-d HP studies when $\mathrm{Li}^{+}$was compared to $\mathrm{Na}^{+}$AGP5 in particular was up-regulated by $+4.69(p=0.034)$ in the HP studies (not all data shown). These findings, which concur with that of $\mathrm{Li}$ et al. [30] suggest that $\mathrm{Li}^{+}$ possesses a specific ion effect on AGP gene behavior. These proteins play an important role in plant cell structure but not all processes associated with AGP proteins are understood [46]. 


\subsection{Heavy-Metal-Associated Domain-Containing Protein Gene Abundance in HP}

In the 1- and 7-d $\mathrm{LiCl}$ exposures, several genes that were related to the heavy-metal protein response were differentially-expressed relative to the control and to equimolar $\mathrm{NaCl}$. These included but were not limited to those listed in Table 7. The genes for these proteins were generally up-regulated in the HP studies (Table 8). This is indicative of a toxic ion response, much like that of other metals. The diversity of heavy-metal response genes was not observed in the soil studies, but some genes such as At5g52760 were highly up-regulated and also high in transcript abundance (Table 11). Li et al. [30] observed the up-regulation of a couple of heavy-metalassociated genes but their gene accession numbers did not match those in our study and the levels of up-regulation after the acute exposure of high levels of $\mathrm{Li}^{+}$were not observed in the study by $\mathrm{Li}$ and researchers.

\subsection{Avirulence-responsive Gene Abundance}

The avirulence-responsive f.p. genes (AIG1 and AIG2) are often associated with system acquired resistance and general stress response in plants. They also influence endocytosis, salicylic acid biosynthetic process, and salicylic acid mediated signaling pathway. AIG1 genes were generally up-regulated in the HP studies with 7-d $1 \mathrm{mM} \mathrm{HP} \mathrm{LiCl} \mathrm{exposures} \mathrm{(Table} \mathrm{8).} \mathrm{The} \mathrm{AIG2} \mathrm{gene} \mathrm{was} \mathrm{not} \mathrm{differentially} \mathrm{expressed} \mathrm{in} \mathrm{the} \mathrm{HP}$ studies but it was with the soil-grown plant shoots and its highest abundance (up-regulation) occurring during wks 4 and 5 relative to the control (Table 11).

\subsection{UDP-Glucosyl Transferase (UGT) and Glutathione S-Transferase (GST) Family Protein Gene Abundance}

The UGT proteins respond to xenobiotic chemicals, are involved with the making of secondary metabolites and they facilitate the addition of a sugar groups to target molecules by the formation of a glycosidic bond. Their up-regulation in the acute exposures is to be expected. Several UGT f.p. genes were up-regulated in the acute 7-d $1 \mathrm{mM} \mathrm{HP} \mathrm{LiCl} \mathrm{exposures} \mathrm{although} \mathrm{a} \mathrm{few} \mathrm{of} \mathrm{the} \mathrm{UGT} \mathrm{genes} \mathrm{were} \mathrm{down-regulated} \mathrm{as} \mathrm{noted} \mathrm{(Table}$ 9). In one case for UGT73D1 in the 7-d exposures, a large fold-change of $+6.02(p=0.002)$ was observed when the $\mathrm{LiCl}$ treatments were compared to the $\mathrm{NaCl}$ treatments. This up-regulation behavior was observed by $\mathrm{Li}$ et al. [30] (within their supplementary data) who studied $\mathrm{Li}^{+}$exposure responses with Brassica (Br.) carinata.

The UGT genes were not highly abundant in the low level soil exposures. A few of them were significantly up- or down-regulated when the treatments were compared with the controls but there were few trends or similarities to that observed of the acute exposures. For example, UGT73B1 in the soil studies, for example was always down-regulated, which was unlike that of the acute treatments. This may be due to the hormesis effect, which may provoke a positive low level type response that is unlike that of an acute response. UGT73D1, which was highly up-regulated in the acute HP exposures was up-regulated in the week 5 treatment plants relative to the week 5 controls $(+1.76, p=0.0002)$ and it also became increasingly up-regulated between wks 3 and $4(+5.32, p=0.0002)$ and wks 4 and $5(+2.97, p=0.00003)$ in the soil treatments but it was not differentially expressed in the soil-based controls from the same time periods.

The glutathione $S$-transferases also respond to xenobiotic chemicals (much like the UGT proteins) via conjugation with reduced glutathione. These enzymes are involved with the scavenging of reactive oxygen species (ROS) species which can form from drought, chilling, high ammonia and viral infection stresses. Like with the UGT protein genes, their up-regulation in the presence of substantial stress is to be expected, as it was observed in the acute (Table 9) and long-term chronic $\mathrm{Li}^{+}$-exposures (Supplementary Table B).

\subsection{Late Embryogenesis Abundant (LEA) Family Protein Gene Abundance}

The LEA proteins often respond to stress, dehydration and low temperature exposure conditions [40]. Nearly all of the LEA genes were up-regulated in the acute 7-d $1 \mathrm{mM} \mathrm{HP} \mathrm{LiCl}$ exposures relative to the $\mathrm{NaCl}$ (Table 9). The 7-d $1 \mathrm{mM} \mathrm{NaCl}$ treatment exhibited up-regulation of LEA3 but up-regulation of LEA3 in the 
equimolar $\mathrm{LiCl}$ treatments relative to $\mathrm{Na}^{+}$was not observed. Much like the UGT family genes, the LEA genes exhibited similar behavior in the soil study. LEA4-5 was down-regulated in wks 3 to 4 of the control as well as the $\mathrm{LiCl}$ soil-based treatments and up-regulated in wks 4 and 5 of the control and $\mathrm{LiCl}$ soil-based treatments. This up-regulation behavior after high level $\mathrm{Li}^{+}$exposure is consistent with the observations of Li et al. [30] with $B r$. carinata.

\subsection{Glycine-rich Protein Gene Abundance}

One of the genes that was significantly up-regulated $(+8.46, p=0.003)$ at in the acute $7-\mathrm{d} 1 \mathrm{mM} \mathrm{HP} \mathrm{LiCl}$ exposures relative to the $\mathrm{NaCl}$ was the gene for the glycine-rich protein 23 (Table 10). Park et al. [57] examined the expression of GRP23 and found that it can be induced by HPA which is a primary constituent of cutin. The PR-1 and PR-5 genes were also induced by HPA in this study. Park and researchers observed that the generation of cutin monomers may induce a pathogen response role as well as provoke the accumulation of peroxide. The addition of foliar abscisic acid as well as salicylic acid also caused the up-regulation of GRP3, GRP5, and GRP23.

\subsection{AAA-type ATPase Family Protein Gene Abundance}

The AAA-type ATPase f.p. are ubiquitous in nature and have diverse roles, such as DNA replication, DNA recombination, DNA repair, protein unfolding (sometimes termed as protein "re-modeling") as reviewed by Snide $e t$ al. [48]. The AAA-type ATPase family proteins in the acute $\mathrm{HP} \mathrm{Li}^{+}$exposures were consistently up-regulated when the $\mathrm{LiCl}$ to $\mathrm{NaCl}$ treatments were compared (Table 10). In the soil exposures, three AAA-type ATPase f.p.s genes were up-regulated relative to the controls but the up-regulation was not restricted to the treatments only. This up-regulation behavior after high level $\mathrm{Li}^{+}$exposure is consistent with the observations of Li et al. [30] that examined Br. carinata. Up-regulation of At3g28580 in the soil studies was apparent during the last weeks of the study relative to the control (as noted in Table 11). Some down-regulation was also observed with time in the controls. It is evident that the low level exposures do not invoke the same responses as the acute high level exposures to $\mathrm{Li}^{+}$.

\subsection{ABC Transporter Family Protein Gene Abundance}

The ABC (ATP-Binding Cassette) transporter genes are known to participate in ATP binding, ATPase activity, the coupling with the transmembrane movement of substances, the glucosinolate biosynthetic process, nucleoside-triphosphatase activity and nucleotide binding in plants. In the acute $\mathrm{HP} 7-\mathrm{d} 1 \mathrm{mM} \mathrm{Li}^{+}$exposure plant shoots, these $\mathrm{ABC}$ transporter genes were up-regulated relative to equimolar 7-d Na${ }^{+}$exposures (Table 10). In contrast, these genes did not exhibit differential regulation in the soil-based studies (data for soil-study not shown). This gene regulation behavior has not been attributed to $\mathrm{Li}^{+}$exposure in prior work with plants. The At1g15520 gene (PDR12) also responds to various stresses including dehydration, heavy-metal ion transport, fungal and bacterial defense, and it exhibits control over hydrogen peroxide metabolism and salicylic acid signaling mediation. Unlike in the HP studies, the PDR12 gene response in the chronic soil-based studies was the same for the control as in the treatment. The linkage of $\mathrm{Li}^{+}$exposure to $\mathrm{ABC}$ transporter genes has not been made with plants to our knowledge.

\subsection{Calcium-ATPase and Calmodulin Gene Abundance}

These genes regulate intracellular $\mathrm{Ca}^{2+}$ levels in cells, which is a major second messenger in cell signaling. The $\mathrm{Ca}^{2+}$-ATPase genes code for proteins that limit $\mathrm{Ca}^{2+}$ levels so the up-regulation of these genes would suppress $\mathrm{Ca}^{2+}$ entry into cells. In the acute $\mathrm{HP} 7-\mathrm{d} 1 \mathrm{mM} \mathrm{LiCl}$ exposure plant shoots, these genes were highly up-regulated relative to equimolar 7-d NaCl exposures (Table 10). This suggests that $\mathrm{Li}^{+}$may be responsible for some dysregulation of $\mathrm{Ca}^{2+}$ levels in the cell and these findings are consistent with that of $\mathrm{Li}$ et al. with $\mathrm{Br}$. carinata and high levels of $\mathrm{LiCl}$. In contrast, these genes did not exhibit differential regulation in the [30] soil-based studies. This gene regulation behavior has been examined in bipolar attributed to $\mathrm{Li}^{+}$exposure in 
prior work with plants. At3g22910 became slightly up-regulated in the low-level chronically-exposed $\mathrm{Li}^{+}$-treated plants from the soil studies, but only between wks 4 and 5 (data for soil-study not shown).

\subsection{Germin-like Protein Gene Abundance}

A linkage between $\mathrm{Li}^{+}$response and GLPs has not been established in plants but GLP9 which had a foldchange of $+9.00(p=0.005)$ for the 7-d LiCl-treated plants relative to the 7-d NaCl-treated plants) was one of the most up-regulated genes that was measured in the entire study (see Table 10). GLP9 was differentially regulated in the controls and treatments from the soil study. After $4 \mathrm{wks}$, the soil-grown $\mathrm{Li}^{+}$-exposed plants had a large fold-change of +6.24 ( $p=0.0000003)$ relative to the controls but similar up-regulation over time occurred in the treatments for wks 3 to 4 and in the controls for wks 4 and 5 so there must be other natural processes that promote significant up-regulation of this gene that are independent of $\mathrm{Li}^{+}$exposure (data for soil-study not shown). The differential regulation of germin-like proteins after high level $\mathrm{Li}^{+}$exposure was not observed by $\mathrm{Li}$ et al. [30]. Hurkman and Tanaka [59] examined the regulation of GLP genes in wheat after infection with powdery mildew. They observed that mRNA for GLP, which converts oxalate to $\mathrm{CO}_{2}$ and $\mathrm{H}_{2} \mathrm{O}_{2}$ will become up-regulated to help with the plant's response to various types of infections. The GLPs are defense response proteins. Three other germin-like genes were observed in the study by Li et al. [30] but they were predominantly down-regulated, which is in contrast to our present study which had highly up-regulated GLP9 upon acute $\mathrm{Li}^{+}$exposure.

\subsection{Peroxidase Gene Abundance}

It is well known that peroxidases will respond to oxidative stress in living organisms so it is somewhat expected that they will be differentially-expressed in plants after exposure to toxic ions. All of the peroxidases were up-regulated in the acute $\mathrm{Li}^{+}$exposure studies after a 7-d exposure (see Table 10). In contrast to the acute $\mathrm{Li}^{+}$-exposure study with HP plants, the $\mathrm{Li}^{+}$-exposed soil-grown plants did not exhibit significant up-regulation of the peroxidases. In one case, the control and the treatment had similar up-regulation behavior for PER50 with time and that suggests there was not a treatment effect of $\mathrm{Li}^{+}$on PER50 (data for soil-study not shown). Li et al. [30] (2009) reported the substantial up-regulation of one peroxidase (At4g23885) in their study but this particular gene was not highly differentially regulated in our study. However, they did see low-level down-regulation of At4g36430 and several other peroxidase genes as well as low-level up-regulation of PER50 and some other peroxidases.

\subsection{Pectinase Gene Abundance}

The high up-regulation of pectin-related genes due to $\mathrm{Li}^{+}$exposure is somewhat unprecedented as observed in our study but most of the pectin-related genes were down regulated in our study and that of Li et al. [30]. Such interactions with pectinesterase may be related to the influence of $\mathrm{Li}^{+}$on free myo-inositol as described by Loewus and Murthy [50]. Free myo-inositol metabolism has a role in pectin synthesis for making cell wall structure. However, the specific up-regulation of one of the pectinesterase genes and the downregulation of another pectinesterase gene in addition to the down-regulation of pectin methylesterase inhibitor superfamily protein makes the data in this study difficult to interpret (see Table 10). It is possible that these pectinesterases are functioning in separate locations in the plants and that explains the inconsistent trend in regulation that is observed. It is possible that the structure of the ER may be influenced by acute high level $\mathrm{Li}^{+}$ exposure due to its impact on the regulation of pectinesterase. Substantial up-regulation of pectinesterase (At2g45220 or PME17) has been observed by Li et al. [30].

\subsection{Fructose-Bisphosphate Aldolase Gene Abundance}

In the MA studies, the fructose-bisphosphate aldolase 5 (AtFBA5) gene was down-regulated (Table 10). This gene codes for a protein that is part of the Calvin cycle and gluconeogenesis. Lu et al. [51] examined the behavior of several of the AtFBA shoot genes to stress and identified AtFBA5 shoot genes to become significantly down-regulated in the presence of cadmium sulfate (heavy-metal stress) but up-regulated in the 
presence of salt, temperature, ethylene, absisic acid and other stresses. Li et al. [30] did not report data on the differential regulation of FBA in their study. FBA requires the incorporation of $\mathrm{Mg}^{2+}$ into its structure. It is possible that $\mathrm{Li}^{+}$may be able to occupy a similar location to that of the $\mathrm{Mg}^{2+}$ and decrease the function of this protein.

Table 11 shows data for AtFBA5 that indicates some up-regulation in the $\mathrm{Li}^{+}$-treated soil-grown plants during wks 3 and 4, which is in contrast to the MA results. This up-regulation behavior in the soil-grown plants may be a hormesis effect but there are probably other explanations which could be pursued but are beyond the present study.

\subsection{Photosystem I and II Gene Abundance}

The MA analyses do not fully cover chloroplast mRNA abundance in depth but the NGS analyses capture much of the chloroplast genes. It is to be expected that young plants will be more photosynthetically-active during their younger days while they prepare for senescence. Table 11 shows the effect of added $\mathrm{Li}^{+}$on the chloroplast transcripts of the soil-grown plants after $1 \mathrm{wk}$ of $0.05 \mathrm{mM} \mathrm{LiCl}$ treatment caused a substantial decrease in the overall abundance of some photosystem II-related gene transcripts (down-regulation of the treatment relative to the control) such as: CAB3 (chlorophyll a/b-binding protein 3); PSAG (photosystem I subunit G); LHCB3 (light-harvesting chlorophyll B-binding protein 3) and several other related proteins that comprise the light-driven reactions in the plant. In some cases, about $50 \%$ of the mRNA abundance was diminished in the $\mathrm{Li}^{+}$treatments relative to the wk 1 control but this varied with gene. However, by wk 2 , the levels of transcript abundance of these photosystem family genes had nearly recovered to levels that were similar to that of the control in wk 2.

\subsection{IAA Gene Abundance}

Lithium can inhibit $\mathrm{Ca}^{2+}$ channels and limits indole acetic acid (IAA)- and nitric oxide-induced adventitious root formation, which is a possible explanation for decreased root biomass after $7 \mathrm{~d}$ of $1 \mathrm{mM} \mathrm{LiCl}$ in the current HP study [52]. This would result in the down-regulation of IAA-type genes in $\mathrm{Li}^{+}$-exposed At roots, but the down-regulation of IAA genes was not observed in the roots after $1 \mathrm{~d}$ of $1 \mathrm{mM} \mathrm{LiCl}$ exposure (unpublished data, not shown). The 1-d HP exposures to $1 \mathrm{mM} \mathrm{LiCl}$ did not result in differential regulation of IAA genes in the shoot tissues. After 7-d exposure, the shoots that were exposed to $1 \mathrm{mM} \mathrm{LiCl}$ showed some measureable changes in IAA gene with IAA3, which was down-regulated (fold-change for $\mathrm{Li}^{+} /$control of -1.85 , $p=0.051$ ) and with IAA17 (fold-change for $\mathrm{Li}^{+} / \mathrm{Na}^{+}$of $-1.87, p=0.027$ ). The $\mathrm{HP} \mathrm{NaCl}$ treatments did not exhibit differential regulation of IAA genes, regardless of exposure time.

As for the soil-grown $0.05 \mathrm{mM} \mathrm{Li}^{+}$-exposed and control At shoots during the first few wks, the levels of mRNA transcripts for all identified IAA genes were similar throughout the $5 \mathrm{wk}$ study (data not shown). There are some slight exceptions in that IAA7 transcripts were detected in the $\mathrm{Li}^{+}$treatment after wk 2 and wk 3 but not in the control, IAA9 was only observed in the control during wks 1 and 2, and IAA14 was only observed in the treatment in wks 1 and 2. However, when both treatment and control produced measureable transcripts of the same IAA gene, the transcript amounts were very similar. All of this suggests that the IAA genes were not greatly affected by $\mathrm{Li}^{+}$in the soil study, which had prolonged low-level $\mathrm{Li}^{+}$exposure.

\subsection{Membrane Exchange and Antiporter Protein Gene Abundance}

There are several cation and proton exchange proteins that are reported to be responsive to $\mathrm{Li}^{+}$as well as other ions (e.g., Zhao et al. [53]). These are the CHX (cation $/ \mathrm{H}^{+}$exchanger), AtNHX (sodium ${ }^{+} / \mathrm{H}^{+}$exchanger) and CAX (cation exchanger) gene series (all of which can be individually identified and sourced by searching for "lithium ion response" in TAIR). The HP studies with $1 \mathrm{mM} \mathrm{LiCl}$ showed the up-regulation of AtNHX6 (At1g79615, fold-change of +1.66 at $p=0.027$ ) and CAX7 (At5g17860, fold-change of +1.78 at $p=0.027$ ) in the 
1-d treatments relative to the control. In the 7-d $1 \mathrm{mM} \mathrm{LiCl} \mathrm{exposure,} \mathrm{CAX3} \mathrm{(At3g51860)} \mathrm{was} \mathrm{up-regulated}$ relative to the $1 \mathrm{mM} \mathrm{NaCl}$ (fold-change of +2.35 at $p=0.001$ ) $\mathrm{HP}$ treatment. It should also be noted that the $1 \mathrm{mM}$ $\mathrm{Li}^{+}$levels that were used were provided as $300 \mathrm{~mL}$ solutions so the available $\mathrm{Li}^{+}$pool was fairly large in $\mathrm{Li}$ by mass per plant (unlike the soil studies).

The $1 \mathrm{mM} \mathrm{NaCl} \mathrm{HP} \mathrm{treatments} \mathrm{did} \mathrm{not} \mathrm{exhibit} \mathrm{similar} \mathrm{gene} \mathrm{expression} \mathrm{behavior} \mathrm{to} \mathrm{the} 1 \mathrm{mM} \mathrm{LiCl} \mathrm{HP}$ treatments, regardless of exposure period. This is somewhat expected because the nutrient media for the control plants already has higher levels of $\mathrm{NaCl}$ than $1 \mathrm{mM} \mathrm{NaCl}$ so the slight increase in the $1 \mathrm{mM} \mathrm{NaCl}$ treatment is practically imperceptible to the plant. The soil-grown $\mathrm{Li}^{+}$-exposed plants did not exhibit differential gene regulation of the membrane cation exchange and antiporter protein genes at the statistical cut-off ( $p$-value) level.

Most cations are transported by proton coupled transporters, rather than primary ion pumps. $\mathrm{Na} / \mathrm{H}$ antiporters fall into three families. The monovalent $\left(\mathrm{H}^{+}, \mathrm{Li}^{+}, \mathrm{K}^{+}\right)$cation:proton antiporter-1 (CPA) family includes eight members, from AtNHX1 to AtNHX8. One recent study by An et al. [54] has identified AtNHX8 up-regulation as being unique to $\mathrm{Li}^{+}$. This response triggers $\mathrm{Li}^{+}$efflux from the cell. Our study did not identify differential regulation of NHX8.

\subsection{Acute vs. Chronic Li ${ }^{+}$Exposure Responses}

Figure 3 depicts a plant's mRNA response plan for high-level acute and low-level chronic $\mathrm{Li}^{+}$exposure. Plant exposure responses to most toxic metals are generally concentration-dependent but the active growth of some plants and the total pool of bioavailable metal have to be considered. Therefore a plant's response is likely to be age-dependent where younger plants are more susceptible to $\mathrm{Li}^{+}$due to their low tissue biomass to $\mathrm{Li}^{+}$ exposure level than older plants which have more biomass at the same $\mathrm{Li}^{+}$exposure level. Furthermore, another factor that may make older plants more tolerant to $\mathrm{Li}^{+}$exposure is the natural emergence of expressed genes for plant defense to predation as the plant ages. The planned emergence of these expressed genes in the older plants should help the plant respond to a toxin whereas younger plants that are putting their energy into growth will have to divert their growth activities to respond to $\mathrm{Li}^{+}$with the necessary expression, much like that of the younger HP plants that were exposed to high levels of $\mathrm{Li}^{+}$. As an example, the soil-grown $\mathrm{Li}^{+}$treatment plants that exhibited similar changes in regulation of the PR protein genes in the HP study were mainly observed after several wks of chronic low level exposure. The older plants in the soil studies did not have differential-regulation of genes of the IMPase and ACC synthase gene families at the statistical cut-off level of $p \leq 0.05$. This may be due to the low $\mathrm{Li}^{+}$ exposure levels and it may be correlated to the fact that the older plants are less sensitive on a per mass basis than the younger plants. The control plants in the soil systems were naturally increasing their levels of PR proteins to help avoid predation while preparing to flower and they may also be more equipped to contend with $\mathrm{Li}^{+}$exposure effects than the younger plants.

Uptake of $\mathrm{Li}^{+}$by plants has some stimulatory effect on plant growth [2]. This type of stimulatory effect may be one of hormesis, where low levels of a perceived toxin prove initially to be beneficial in some manner [55-57]. In the case of $\mathrm{Li}^{+}$and plants, such initial beneficial effects are most likely from the production of ethylene at low $\mathrm{Li}^{+}$concentrations.

At high concentrations, $\mathrm{Li}^{+}$has a substantial adverse effect on cellular processes and growth. Root and shoot biomass quantities, for instance, will become diminished after a 7-d (acute) exposure to $\mathrm{Li}^{+}$at 4 to $12 \mathrm{ppm}$ [58] and at $1 \mathrm{mM} \mathrm{LiCl}$ (as in this study with $\mathrm{HP}$ growth conditions). High $\mathrm{Li}^{+}$concentrations cause excessive ethylene production as well as induction (up-regulation) of proton-coupled transporters and antiporters that will appear to mimic some salinity stress effects. Hawrylak-Nowak et al. [34] examined the effect of $\mathrm{Li}^{+}$-induced lipid peroxidation and concluded that $\mathrm{Li}^{+}$peroxidation of cell membranes occurs and that excessive $\mathrm{Li}^{+}$will cause the accumulation of ROS in plants, much like it does in animals. 
Our study findings with the acute HP-based $\mathrm{Li}^{+}$-exposures on gene expression compare well with that of Bueso et al. [59] who examined catalase 2 mutant responses to high levels of $\mathrm{Li}^{+}$and with those of $\mathrm{Li}$ et al. [30] who examined the effect of $\mathrm{Li}^{+}$on $\mathrm{Br}$. carinata seedlings. Collectively, acute, high concentration $\mathrm{Li}^{+}$-induced gene responses invoke differential regulation of trypsin, calmodulin, heavy-metal associated domain-containing proteins, beta-1,3, glucanase, PR proteins, and glutathione $S$-transferases. The uptake of $\mathrm{Li}^{+}$is primarily by the hydrogen proton pump process. This mechanism is unique to monovalent cations including $\mathrm{Na}^{+}, \mathrm{Li}^{+}$and $\mathrm{K}^{+}$. Lithium and $\mathrm{Na}$ ions elicit similar homeostasis restoration responses. As such, $\mathrm{Li}^{+}$is often used experimentally to specifically examine a plant's stress signaling and response, unlike $\mathrm{Na}^{+}$which is used more often for salinity response.

Little is known about the receptors that sense stress but several downstream signaling cascades have been identified and studied. Stresses may lead to an increase in reactive oxygen species (ROS), glutamate transporters, cystosolic $\mathrm{Ca}^{2+}, \mathrm{ABC}$ transporter gene up-regulation ([34] and in this study). Ultimately, many of these signaling cascades result in altered or increased expression of stress-responsive genes that are produced as part of the plant's normal growth processes - as noted in this study. Some of these encode proteins responsible for the biosynthesis of hormones, such as abscisic acid, which can act as signaling molecules that amplify and spread the initial stress signal.

\section{Conclusions}

With additional study, this information has the potential application of serving as a method of detection of damaging $\mathrm{Li}^{+}$(as opposed to other ions like $\mathrm{Na}^{+}$) exposure in the agricultural and natural environment or for selecting more $\mathrm{Li}^{+}$-tolerant plant varieties within the same plant species for cultivation - to make better use of $\mathrm{Li}^{-}$ rich irrigation waters. Alternative methods of qualifying and quantifying $\mathrm{Li}^{+}$exposure in the environment are relevant to detecting contamination plumes and evaluation of environmental remediation approaches, decisions about agricultural irrigation water use, and the evaluation of crop health.

It should be noted that this study did not examine the effect of $\mathrm{Li}^{+}$on the plant proteome (including its substitution for structural $\mathrm{Mg}^{2+}$ ) and it is possible that there are differences in what can be interpreted from the proteome vs. the transcriptome (such as noted by Ghazalpour et al. [60]). Our study elucidates the differences between high level acute $\mathrm{Li}^{+}$exposure and chronic low-level $\mathrm{Li}^{+}$exposure in plants. The effect that low level $\mathrm{Li}^{+}$ has on greater cellular organization, increased metabolic processes, and enhanced ability to handle stress and terms of signaling may have relevance to mammalian systems. In our study, $\mathrm{Li}^{+}$exposure influenced a few genes that had not been identified to respond to $\mathrm{Li}^{+}$in prior studies, such as AtFBA5 and GLP9. Because AtFBA5 requires $\mathrm{Mg}^{2+}$ to function and was down-regulated with $\mathrm{Li}^{+}$exposure, the data suggest that that $\mathrm{Li}^{+}$may play a larger role in the inhibition of other $\mathrm{Mg}^{2+}$-containing proteins in plant as well as mammalian systems. Upregulation of the GLP9 gene suggests that cell wall structure becomes greatly modified upon $\mathrm{Li}^{+}$uptake, which is consistent with up-regulation response of other cell-wall related genes in this study. Furthermore, more support for the wide ranging effects of $\mathrm{Li}^{+}$on protein behavior is that a systemic $\mathrm{Mg}^{2+}$ deficiency also explains the observed changes in circadian rhythms in Arabidopsis [61]. Transcriptome profiling by Hermans and researchers [61] revealed several gene regulation similarities to that of the acute $\mathrm{Li}^{+}$toxicity responses in our current study, which further supports a $\mathrm{Li}^{+}$-induced $\mathrm{Mg}^{2+}$ deficiency but $\mathrm{Li}$ probably has an effect on overall $\mathrm{Ca}^{2+}$ levels as well in plants and other organisms. Wallace [11] recently considered the possible link between $\mathrm{Ca}^{2+}$-ATPase and Alzheimers Disease and suggests that $\mathrm{Li}^{+}$may be responsible for the intracellular control of $\mathrm{Ca}^{2+}$ levels in the cell to help preclude the progression of the disease. Khoury et al. [62] has observed such decreases in intracellular $\mathrm{Ca}^{2+}$ levels in bipolar patients upon the addition of Li-treatment in women. We suggest that the effect of $\mathrm{Li}^{+}$on the treatment of bipolar affective disorder and other neurological diseases may also be related to its ability to decrease the level and mobility of intracellular $\mathrm{Mg}^{2+}$ as well as $\mathrm{Ca}^{2+}$ levels. 


\section{Acknowledgements}

This project was conducted in conjunction with work accomplished under Contract No. DE-AC0908SR22470 with the U.S. Dept. of Energy. This work was supported by U.S. DOE-National Nuclear Security Administration through the Office of Defense Nuclear Nonproliferation Research and Development-NA-22 (Grant No. DE-FG52-05NA27035). 


\section{References}

[1] W. Tahil, The trouble with lithium. Implications of future PHEV production for lithium demand, Meridian International Research, (2007) 1-14.

[2] H. Aral, A. Vecchio-Sadus, Toxicity of lithium to humans and the environment-A literature review, Ecotoxicology and Environ. Safety, 70 (2008) 349-356.

[3] L.A. Kszos, A.J. Stewart, Review of lithium in the aquatic environment: Distribution in the United States, toxicity and case example of groundwater contamination, Ecotoxicology, 12 (2003) 439-447.

[4] G.N. Schrauzer, Lithium: Occurrence, dietary intakes, nutritional essentiality, J. American College of Nutrition, 21 (2002) 14-21.

[5] M. Anke, B. Groppel, H. Kronemann, M. Grün, Evidence for the essentiality of lithium in goats, in: M. Anke (Ed.) Proc. 4 Spurenelement Sympos. Jena: VEB Kongressdruck, 1983, pp. 58-65.

[6] M. Anke, W. Arnhold, U. Groppel, U. Krause, The biological importance of lithium in: G.N. Schrauzer, K.F. Klippel (Eds.) Lithium in Biology and Medicine, VCH Verlag, Weinheim, 1991, pp. 149-167.

[7] W. Arnhold, M. Anke, Further evidence of the essentiality of lithium in ruminants, in: M. Anke (Ed.) Proc. 6th International Trace Elements Sympos. 1989, Jena: Univ. of Jena Publication Dept., 1989, pp. 1241-1261.

[8] E.E. Pickett, B.L. O’Dell, Evidence for dietary essentiality of lithium in the rat, Biological Trace Elements Research, 34 (1992) 299-319.

[9] E.L. Patt, E.E. Pickett, B.L. O’Dell, Effect of dietary lithium levels on tissue lithium concentrations, growth rate, and reproduction in the rat, Bioinorganic Chemistry, 9 (1978) 299-310.

[10] F.T. Bingham, G.E. Bradford, A.L. Page, Toxicity of lithium, California Agriculture, 18 (1964) 6-7.

[11] J. Wallace, Calcium dysregulation, and lithium treatment to forestall Alzheimer's disease - a merging of hypotheses, Cell Calcium, 55 (2014) 175-181.

[12] D.J.M. Peters, M.M. Van Lookeren Campgne, P.J. Van Haasstert, M.W. Spek, P. Schaap, Lithium ions induce prestalk-associated gene expression and inhibits prespore gene expression in Dictyotelium discoideum, J. Cell Science, 93 (1989) 205-210.

[13] P.D. Nieukwoop, The organization center of the amphibian embryo: Its origin, spatial organization, and morphogenitic action, Ad Morphog, 10 (1973) 1-39.

[14] G.E. Bradford, Lithium in California's water resources, California Agriculture, 17 (1963) 6-7.

[15] L.M. Hallcher, W.R. Sherman, The effects of lithium ion and other agents on the activity of myo-inositol-1phosphatase from bovine brain, J. Biology and Chemistry, 255 (1980) 10896-10901.

[16] K.M. Brown, D.K. Tracy, Lithium: the pharmacodynamic actions of the amazing ion, Therapeutic Advances in Psychopharmacology, 3 (2013) 163-176.

[17] A. Haimovich, U. Eliav, A. Goldbourt, Determination of the lithium binding site in inositol monophosphatase, the putative target for lithium therapy, by magic-angle-spinning solid-state NMR, J. American Chemical Society, 134 (2012) 5647-5651.

[18] T. Dudev, C. Lim, Competition between $\mathrm{Li}^{+}$and $\mathrm{Mg}^{2+}$ in metalloproteins. Implications for lithium therapy, J. American Chemical Society, 133 (2011) 9506-9515.

[19] C. Srinivasan, J. Toon, L. Amari, A.M. Abukhdeir, H. Hamm, C.F.G.C. Geraldes, Y.-K. Ho, D.M. de Freitas, Competition between lithium and magnesium ions for the G-protein transduction in the guanosine 5'-diphosphate bound conformation, J. Inorganic Biochemistry, 98 (2004) 691-701.

[20] M.J. Berridge, Inositol triphosphate and calcium signalling, Nature, 361 (1993) 315-325.

[21] G.E. Gillaspy, J.S. Keddle, K. Oda, W. Gruissem, Plant inositol monophosphatase is a lithium-sensitive enzyme encoded by a multigene family, The Plant Cell, 7 (1995) 2175-2185.

[22] G.E. Gillaspy, W. Gruissem, $\mathrm{Li}^{+}$induces hypertrophy and down regulation of myo-inositol monophosphatase in tomato, J. Plant Growth and Regulation, 20 (2001) 78-86.

[23] J.C. Styer, J. Keddie, J. Spence, G.E. Gillaspy, Genomic organization and regulation of the LeIMP-1 and LeIMP-2 genes encoding myo-inositol monophosphatase in tomato, Gene, 326 (2004) 35-41.

[24] B. Dichtl, A. Stevens, D. Tollervey, Lithium toxicity in yeast is due to the inhibition of RNA processing enzymes, EMBO J., 16 (1997) 7184-7195. 
[25] X. Liang, N.F. Shen, A. Theologis, $\mathrm{Li}^{+}$-regulated 1-aminocyclopropane-1-carboxylate synthase gene expression in Arabidopsis thaliana, The Plant J., 10 (1996) 1027-1036.

[26] T. Jung, J.H. Lee, M.H. Cho, W.T. Kim, Induction of 1-aminocyclopropane-1-carboxylate oxidase mRNA by ethylene in mung bean roots: possible involvement of $\mathrm{Ca}^{2+}$ and phosphoinositides in ethylene signaling, Plant Cell Env., 23 (2000) 205-213.

[27] T. Boller, Superinduction of ACC synthase in tomato pericarp by lithium ions, in: Y. Fuchs, E. Chalutz (Eds.) Ethylene: biochemical, physiological, and applied aspects, Nijoff/Junk, the Hague, 1984, pp. 87-88.

[28] T. Sato, A. Theologis, Cloning the mRNA encoding 1-aminocyclopropane-1-carboxylate synthase, the key enzyme for ethylene biosynthesis in plants, Proc. National Academy of Sciences, 86 (1989) 6621-6625.

[29] M.A. Naranjo, C. Romero, J.M. Belles, C. Montesinos, O. Vicente, R. Serrano, Lithium treatment induces a hypersensitive-like response in tobacco, Planta, 217 (2003) 417-424.

[30] X. Li, P. Gao, B. Gjetvaj, N. Westcott, M.Y. Gruber, Analysis of the metabolome and transcriptome of Brassica carinata seedlings after lithium chloride exposure, Plant Science, 177 (2009) 68-80.

[31] Y. Mishra, Z.A. Kiss, H.J. Jänkänpää, C. Funk, P.W. Schröder, S. Jansson, Arabidopsis plants grown in the field and climate chambers significantly differ in leaf morphology and photosystem components, BMC Plant Biology 12 (2012) 6.

[32] D. Murphy, Gene expression studies using microarrays: Principles, problems and problems, Advances in Physiol. Education, 26 (2002) 256-270.

[33] M.C. Van Verk, R. Hickman, C.M.J. Pieterse, S.C.M. Van Wees, RNA-Seq: revelation of the messengers, Trends in Plant Science, 18 (2013) 175-179.

[34] B. Hawrylak-Nowak, M. Kalinowska, M. Szymańska, A study on selected physiological parameters of plants grown under lithium supplementation, Biological Trace Elements Research, 149 (2012) 425-430.

[35] N.E. Martinez, T.E. Johnson, W.W. Kuhne, C.T. Stafford, M.C. Duff, Feasibility assessment of reflectance spectroscopy to detect $\mathrm{LiCl}$ stress across four plant species, J. Near Infrared Spectroscopy, In preparation (2014). [36] N.E. Martinez, Selected techniques in radioecology: model development and comparison for internal dosimetry of rainbow trout (Oncorhynchus mykiss) and feasibility assessment of reflectance spectroscopy use as a tool in phytoremediation, in: Dept. Environ. Radiological Health Sciences, Colorado State Univ., Ft Collins, CO, 2014, pp. 262.

[37] L. Taiz, E. Zeiger, Plant Physiology, Fifth ed., Sinaeur Associates, Publishing, Sunderland, MA, USA, 2010. [38] T.Z. Berardini, S. Mundodi, R. Reiser, E. Huala, M. Garcia-Hernandez, P. Zhang, L.M. Mueller, J. Yoon, A. Doyle, G. Lander, N. Moseyko, D. Yoo, I. Xu, B. Zoeckler, M. Montoya, N. Miller, D. Weems, S.Y. Rhee, Functional annotation of the Arabidopsis genome using controlled vacobularies, Plant Physiol., 135 (2004) 1-11. [39] T. Akamatsu, Y. Hanzawa, Y. Ohtake, T. Takahashi, K. Nishitani, Y. Komeda, Expression of endoxyloglucan transferase genes in acaulis mutants of Arabidopsis, Plant Physiol., 121 (1999) 715-721. [40] M. Hundertmark, D.K. Hincha, LEA (Late Embryogenesis Abundant) proteins and their encoding genes in Arabidopsis thaliana, BMC Genomics, 9 (2008) 1471-2164.

[41] T.K. Prasad, M.D. Anderson, C.R. Stewart, Acclimation, hydrogen peroxide, and abscisic acid protect mitochondria against irreversible chilling injury in maize seedlings, Plant Physiol., 105 (1994) 619-627. [42] T.K. Prasad, M.D. Anderson, B.A. Martin, C.R. Stewart, Evidence for chilling-induced oxidative stress in maize seedlings and a regulatory role for hydrogen peroxide, Plant Cell, 6 (1994) 65-74.

[43] N.R. Hoffman, Alternative splicing links the circadian clock to cold tolerance, Plant Cell, 24 (2012) 223.

[44] H. Knight, A.J. Trewavas, M.R. Knight, Cold calcium signaling in Arabidopsis involves two cellular pools and a change in calcium signature after acclimation, Plant Cell, 8 (1996) 489-503.

[45] D. Szklarczyk, A. Franceschini, M. Kuhn, M. Simonovic, A. Roth, P. Minguez, T. Doerks, M. Stark, J. Muller, P. Bork, L.J. Jensen, C. von Mering, The STRING database in 2011: Functional interaction networks of proteins, globally integrated and scored, Nucleic Acids Research, 39 (2011).

[46] T. Tryfona, H. Liang, T. Kotake, Y. Tsumuraya, E. Stephens, P. Dupree, Structural characterization of Arabidopsis leaf arabinoglactan polysaccharides, Plant Physiol., 160 (2012) 653-666.

[47] J.H. Park, M.C. Suh, T.H. Kim, M.C. Kim, S.H. Cho, Expression of glycine-rich protein genes, AtGRP5 and AtGRP23, induced by the cutin monomer 16-hydroxypalmitic acid in Arabidopsis thaliana, Plant Physiol.

Biochemistry, 46 (2008) 1015-1018. 
[48] J. Snide, G. Thibault, W.A. Houry, The AAA+ superfamily of functionally diverse proteins, Genome Biology, 9 (2008) 216.

[49] W.J. Hurkman, C.K. Tanaka, Germin gene expression is induced in wheat leaves by powdery mildew infection, Plant Physiol., 111 (1996) 735-739.

[50] F.A. Loewus, P.P.N. Murthy, myo-Inositol metabolism in plants, Plant Science, 150 (2000) 1-19.

[51] W. Lu, X. Tang, Y. Huo, R. Xu, Q. Shengdong, J. Huang, C. Zheng, C.-a. Wu, Identification and characterization of fructose 1,6-bisphosphate aldolase genes in Arabidopsis reveal a gene family with diverse responses to abiotic stresses, Gene, 503 (2012) 65-74.

[52] L.M. Lanteri, G.C. Pagnussat, L. Lamattina, Calcium and calcium-dependent protein kinases are involved in nitric oxide- and auxin-induced adventitious root formation in cucumber, J. Experimental Botany, 57 (2006) 1341-1351.

[53] J. Zhao, B.J. Barkla, J. Marshall, J.K. Pittman, K.D. Hirschi, The Arabidopsis cax3 mutants display altered salt tolerance, $\mathrm{pH}$ sensitivity and reduced plasma membrane $\mathrm{H}^{+}$-ATPase activity, Planta, 227 (2008) 659-669.

[54] R. An, Q.J. Chen, M.F. Chai, P.L. Lu, Z. Su, Z.X. Qin, J. Chen, X.C. Wang, AtNHX8 a member of the monovalent cation:proton antiporter-1 family in Arabidopsis thaliana, encodes a putative $\mathrm{Li} / \mathrm{H}$ antiporter, Plant J., 49 (2007) 718-728.

[55] E.J. Calabrese, Evidence that hormesis represents and "overcompensation" response to a disruption in homeostasis, Ecotoxicology and Environ. Safety, 42 (1999) 135-137.

[56] E.J. Calabrese, L.A. Baldwin, Hormesis: The dose-response revolution, Annual Rev. Pharmacology, 43 (2003) 175-197.

[57] K. Kosová, P. Vítámvás, I.T. Prášil, J. Renaut, Plant proteome changes under abiotic stress - Contribution of proteomics studies to understanding plant stress response, J. Proteomics, 74 (2011) 1301-1322.

[58] N.G. McStay, H.H. Rogers, C.E. Anderson, Effect of lithium on Phaseolus vulgaris L., Science of the Total Env., 16 (1980) 185-191.

[59] E. Bueso, S. Alejandro, P. Carbonell, M.A. Perez-Amador, J. Fayos, J.M. Bellés, P.L. Rodriguez, R. Serrano, The lithium tolerance of the Arabidopsis cat 2 mutant reveals a cross-talk between oxidative stress and ethylene, Plant J., 52 (2007) 1052-1065.

[60] A. Ghazalpour, B. Bennett, V.A. Petyuk, L. Orozco, R. Hagopian, I.N. Mungrue, C.R. Farber, J. Sinsheimer, H.M. Kang, N. Furlotte, C.C. Park, P.Z. Wen, H. Brewer, K. Weitz, D.G.I. Camp, C. Pan, R. Yordanova, I.

Neuhaus, C. Tilford, N. Siemers, P. Gargalovic, E. Eskin, T. Kirchgessner, D.J. Smith, R.D. Smith, A.J. Lusis, Comparative analysis of proteome and transcriptome variation in mouse, PLoS Genetics 7 (2011).

[61] C. Hermans, M. Vuylsteke, F. Coppens, A. Craciun, D. Inzé, N. Verbruggen, Early transcriptomic changes induced by magnesium deficiency in Arabidopsis thaliana reveal the alteration of circadian clock gene expression in roots and the triggering of abscisic acid-responsive genes. New Phytologist, 187 (2010) 119-31.

[62] A. El Khourya, U. Pettersona, G. Kallnerb, A. Åberg-Wistedta, R. Stain-Malmgren, Calcium homeostasis in long-term lithium-treated women with bipolar affective disorder, Progress in Neuro-Psychopharmacology \& Biological Psychiatry 26 (2002) 1063-1069. 
Figure 1. Images of control 33-d old plants that were given nutrient media (control, left image) and or $1 \mathrm{mM}$ $\mathrm{LiCl}$ (right image) for $7 \mathrm{~d}$. Chlorosis and shriveling are visible in the treatment plants.

Figure 2. Plot of $\mathrm{Li}^{+}$uptake with respect to time [1.0 $\mathrm{mM} \mathrm{Li}^{+}$is equal to $0.694 \mathrm{mg} \mathrm{Li}^{+} \mathrm{L}^{-1}$ of $\mathrm{HP}$ media.]

Figure 3. The plant's mRNA response plan for $\mathrm{Li}^{+}$exposure is likely to be related to the amount of available $\mathrm{Li}^{+}$ as well as time. In actively-growing plants which have short lifetimes like At, the amount of plant biomass is likely to dictate the plant's type of response (acute or chronic). 

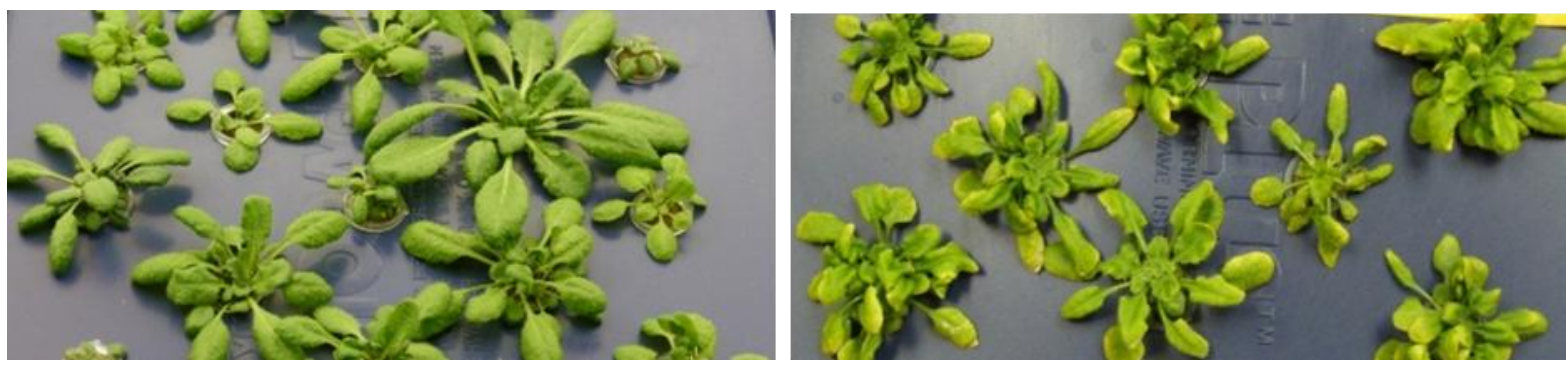

Figure is for color reproduction on the Web (free of charge) and in print 


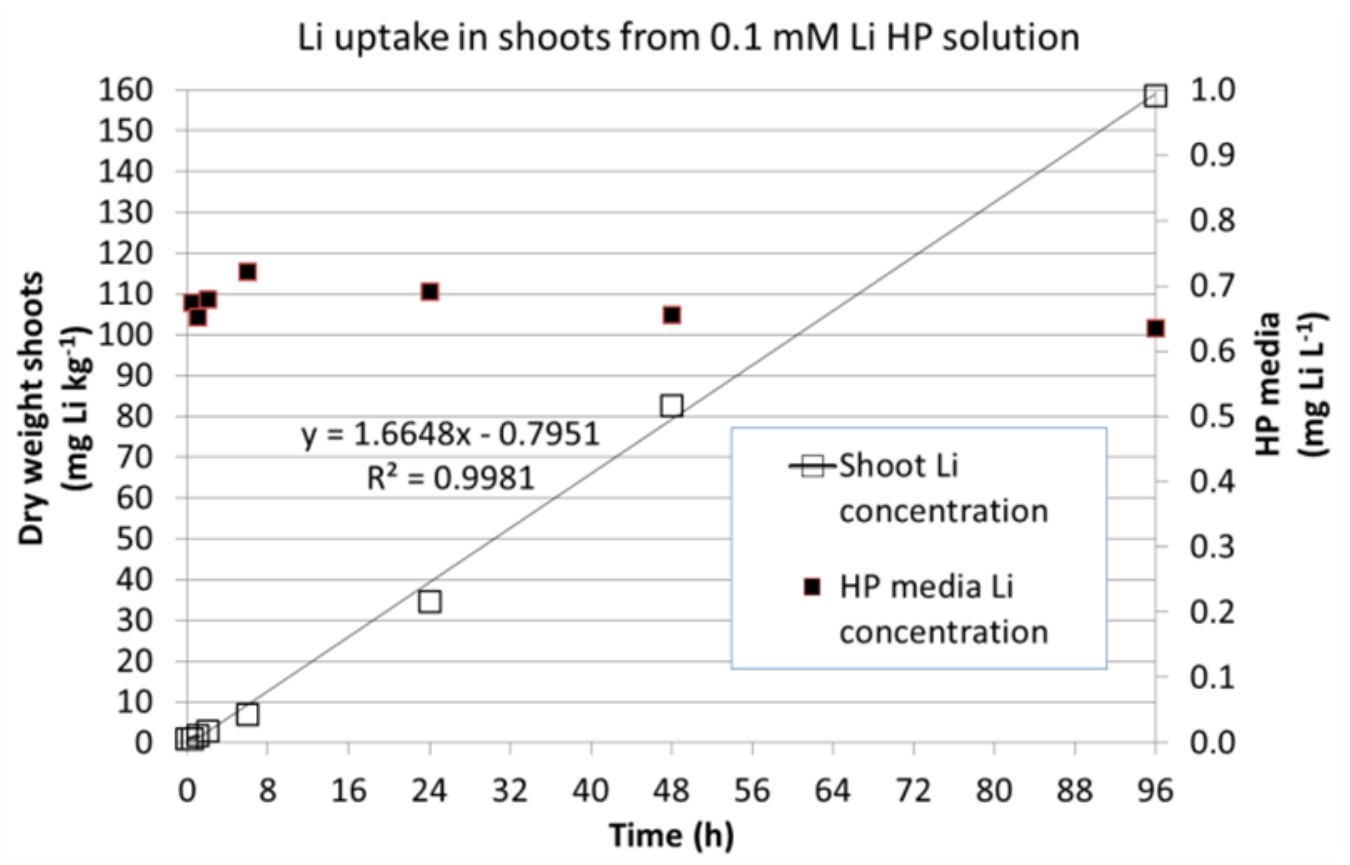

Figure is for black and white reproduction on the Web (free of charge) and in print 


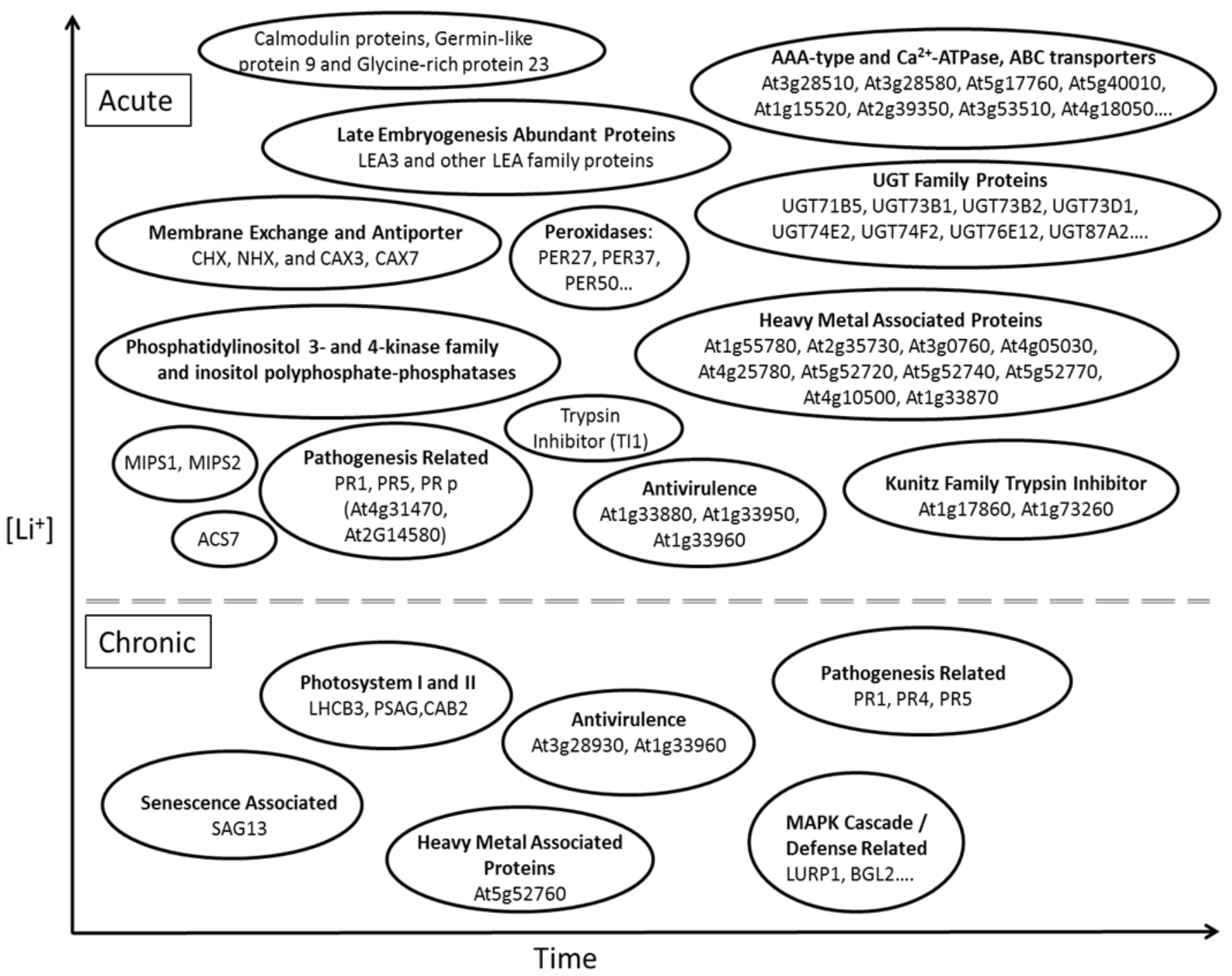


Table 1. List of experimental conditions used with plants in this study. The media in the HP studies was not changed during the exposure period.

\begin{tabular}{|c|c|c|c|c|}
\hline Medium & Treatment and Associated Concentration & $\begin{array}{c}\text { Exposure } \\
\text { Periods }\end{array}$ & $\begin{array}{c}\text { Age at } \\
\text { Treatment } \\
\text { Start (d) }\end{array}$ & $\begin{array}{c}\text { RNA Analysis } \\
\text { Method with Shoots* }\end{array}$ \\
\hline HP & 0 (control) and 1 mM LiCl in 1/32 strength \\
MS media & 1 and 7 d & 26 & MA \\
\hline HP & $1 \mathrm{mM} \mathrm{NaCl} \mathrm{in} \mathrm{1/32} \mathrm{strength} \mathrm{MS} \mathrm{media}$ & 1 and 7 d & 26 & MA \\
\hline HP & $0.1 \mathrm{mM} \mathrm{LiCl} \mathrm{kinetic} \mathrm{study}$ & 1 to $96 \mathrm{~h}$ & 43 & Not applicable \\
\hline $\begin{array}{c}\text { Soil in } \\
\text { square } \\
\text { pot }\end{array}$ & $\begin{array}{c}0 \text { (control) and 0.05 mM LiCl in 1/64 } \\
\text { strength MS media, 100 mL per watering } \\
\text { with 25 mL per pot quadrant twice weekly }\end{array}$ & $\begin{array}{c}\text { Four wks plus 2 wks } \\
\text { depuration using } 1 / 64 \\
\text { HP twice weekly }\end{array}$ & 37 & $\begin{array}{c}\text { NGS. Plants sampled } \\
\text { after wk } 1,2,3,4, \text { and } \\
5 \text { of LiCl exposure }\end{array}$ \\
\hline
\end{tabular}

*MA: MicroArray; NGS: Next Generation Sequencing. 
Table 2. TAIR GO functional analysis search engine for biological function of all genes that met the statistical cut-off. Whole genome information from TAIR is provided for reference.

\begin{tabular}{|c|c|c|c|c|c|c|}
\hline Biological Function & $\begin{array}{c}\text { Whole } \\
\text { Genome } \\
\text { N=24621 }\end{array}$ & $\begin{array}{c}\text { Wk 1 }(\%) \\
\text { N=1216; } \\
\text { Gene IDs: } \\
2463 ; \\
199037 \\
\text { FPKM* }\end{array}$ & $\begin{array}{c}\text { Wk } 2(\%) \\
\text { N=1514; } \\
\text { Gene IDs: } \\
\text { 3006; } \\
160797 \\
\text { FPKM } \\
\end{array}$ & $\begin{array}{c}\text { Wk 3 (\%) } \\
\text { N=1583; } \\
\text { Gene IDs: } \\
\text { 3213; } \\
\text { 168729 } \\
\text { FPKM }\end{array}$ & $\begin{array}{c}\text { Wk } 4(\%) \\
\text { N=292; } \\
\text { Gene IDs: } \\
\text { 622; } \\
38709 \\
\text { FPKM } \\
\end{array}$ & $\begin{array}{c}\text { Wk } 5(\%) \\
\text { N=338; } \\
\text { Gene IDs: } \\
744 ; \\
21304 \\
\text { FPKM }\end{array}$ \\
\hline Cell organization and biogenesis & 13.6 & 10.2 & 7.3 & 7.1 & 4.4 & 3.5 \\
\hline Developmental processes & 15.6 & 8.2 & 7.5 & 7.2 & 6.5 & 5.6 \\
\hline DNA or RNA metabolism & 3.7 & 0.6 & 1.3 & 1.6 & 0.3 & 0.0 \\
\hline Electron transport or energy pathways & 2.8 & 4.1 & 1.1 & 1.1 & 0.7 & 0.6 \\
\hline Other biological processes & 14.8 & 18.0 & 18.0 & 18.4 & 30.1 & 29.3 \\
\hline Other cellular processes & 56.7 & 52.1 & 47.7 & 47.8 & 49.3 & 47.6 \\
\hline Other metabolic processes & 53.6 & 52.0 & 46.3 & 46.8 & 48.3 & 47.3 \\
\hline Protein metabolism & 21.3 & 16.4 & 17.5 & 17.3 & 13.0 & 13.3 \\
\hline Response to abiotic or biotic stimulus & 15.3 & 15.3 & 19.2 & 19.2 & 31.5 & 31.4 \\
\hline Response to stress & 16.6 & 18.4 & 20.7 & 21.3 & 35.6 & 37.3 \\
\hline Signal transduction & 8.1 & 7.6 & 11.8 & 12.2 & 18.3 & 17.7 \\
\hline Transcription, DNA-dependent & 10.6 & 6.5 & 6.0 & 6.4 & 4.8 & 4.7 \\
\hline Transport & 14.3 & 13.6 & 13.5 & 13.6 & 19.5 & 21.0 \\
\hline Unknown biological function & 32.9 & 38.5 & 42.6 & 42.6 & 36.3 & 37.0 \\
\hline
\end{tabular}

* FPKM: Sum of Fragments Per Kilobase of transcript per Million mapped reads.

\footnotetext{
${ }^{1}$ The age of the plant that contributed the whole genome information in TAIR was not known.
} 
Table 3. List of the 61 genes that were up-regulated at wk 5 relative to wk 4 in the soil-grown control plants that met the $p$-value of $\leq 0.05$.

\begin{tabular}{|c|c|}
\hline Accession No. & Gene Name; Function \\
\hline AAP2 & Amino Acid transmembrane transporter \\
\hline ACD6 & Accelerated Cell Death 6 \\
\hline AOC1 & P-P bond hydrolysis drive protein transmembrane transporter activity \\
\hline $\mathrm{AOC} 2$ & Allene Oxide Cyclase 2; senescence; defense response \\
\hline ARR7 & Response regulator 7 \\
\hline At1g27020 & Unknown \\
\hline At1g35710 & Defense response \\
\hline At1g55210 & Disease resistance responsive; defense response \\
\hline At1g58225 & Unknown \\
\hline At1g76960 & Unknown \\
\hline At2g18690 & Defense response \\
\hline At2g41090 & Calcium-binding EF-hand f.p. \\
\hline At2g43530 & Defense response \\
\hline At3g16530 & Defense response \\
\hline At3g22235 & Pathogenesis-Related \\
\hline At3g22600 & Lipid transport; response to nitrate \\
\hline At3g28220 & Regulation of anthocyanin biosynthetic process; defense response \\
\hline At3g28540 & ATP binding \\
\hline At3g47480 & Calcium ion binding; defense response \\
\hline At3g55240 & Development \\
\hline At3g60420 & Defense response \\
\hline At4g24920 & SecE/sec61-gamma protein transport protein \\
\hline At4g38840 & Small auxin up-regulated RNA 14; defense response \\
\hline At5g05600 & Iron ion binding; jasmonic acid biosynthetic process; defense response \\
\hline At5g50460 & P-P bond hydrolysis drive protein transmembrane transporter activity \\
\hline At5g55450 & Lipid binding; defense response \\
\hline AtERDJ3B & Defense response \\
\hline AZI1 & AZelaic acid Induced 1; pathogenesis-response \\
\hline BGL2 & PR protein 2 \\
\hline BIP1 & Luminal binding protein 1 \\
\hline BIP2 & Luminal binding protein 2 \\
\hline $\mathrm{CHI}$ & Chitin binding \\
\hline CNX1 & Defense response \\
\hline CRK4 & Pathogenesis-response; programmed cell death \\
\hline CRK6 & Protein phosphorylation \\
\hline CRT1a & $\mathrm{Ca}^{2+}$ binding \\
\hline CRT1b & Defense response; response to $\mathrm{H}_{2} \mathrm{O}_{2}$ \\
\hline CRT3 & Calcium ion binding; defense response \\
\hline DMR6 & Defense response \\
\hline DR4 & Drought Repressed 4; water deprivation \\
\hline GSR 1 & Arabidopsis glutamine synthase 1 \\
\hline GSTF6 & Glutathione $S$-transferase 6 ; defense response \\
\hline GSTF7 & Glutathione $S$-transferase 7 ; defense response \\
\hline LURP1 & PR protein \\
\hline PCC1 & Pathogen and Circadian Controlled 1 \\
\hline
\end{tabular}




\begin{tabular}{|c|c|}
\hline PCR1 & Plant cadmium resistance 1 \\
\hline PDIL1-1 & Protein disulfide isomerase 5; programmed cell death \\
\hline PDIL1-2 & Protein disulfide isomerase 6; defense response \\
\hline pEARLI 1 & Early Arabidopsis Aluminum Induced 1; defense response \\
\hline PR1 & PR gene 1 \\
\hline PR5 & PR gene 5 \\
\hline PRXCB & Cell elongation; defense response to $\mathrm{H}_{2} \mathrm{O}_{2}$ \\
\hline RING1 & PR protein; programmed cell death \\
\hline SDF2 & Stromal cell derived factor 2; defense response \\
\hline SHD & Heat shock protein \\
\hline SUC1 & Sucrose transporter \\
\hline TI1 & Trypsin Inhibitor 1; defense response \\
\hline WAK1 & Cell wall associated kinase 1; defense response \\
\hline YLS5 & Defense response; leaf senescence \\
\hline
\end{tabular}

* f.p.: family protein. 
Table 4. List of genes with the top 100 most abundant transcripts in the soil-grown control plants that met the $p$ value of $\leq 0.05$. Pink boxes represent up-regulation and green boxes represent down-regulation.

\begin{tabular}{|c|c|c|c|c|c|}
\hline $\begin{array}{l}\text { Accession } \\
\text { No. }\end{array}$ & Gene Name*; Function & $\begin{array}{l}\text { Wks } \\
1 \text { to } 2\end{array}$ & \begin{tabular}{|c|c|} 
Wks \\
2 to 3 \\
\end{tabular} & \begin{tabular}{|c|c|} 
Wks \\
3 to 4 \\
\end{tabular} & \begin{tabular}{|l|l|} 
Wks \\
4 to 5 \\
\end{tabular} \\
\hline ACS6 & $\begin{array}{l}\text { 1-aminocyclopropane-1-carboxylic acid; protein binding; stress } \\
\text { response }\end{array}$ & & & & \\
\hline AGP12 & Arabinogalactan protein 12; cell signaling & & & & \\
\hline AOC1 & $\begin{array}{c}\text { Allene Oxide Cyclase 1; early response to dehydration 12; } \\
\text { senescence }\end{array}$ & & & & \\
\hline AOC2 & Allene Oxide Cyclase 2; senescence & & & & \\
\hline ASN1 & Glutamine-dependent asparagine synthase 1 & & & & \\
\hline At1g07135 & Response to wounding & & & & \\
\hline At1g12440 & A20/N1-like zinc finger f.p.; DNA binding, zinc ion binding & & & & \\
\hline At1g18740 & Flavonoid biosynthetic process; defense response & & & & \\
\hline At1g22190 & Related to AP2 4; transcription factor, defense response & & & & \\
\hline At1g23710 & Unknown function (DUF1645); defense response & & & & \\
\hline At1g32920 & Response to wounding & & & & \\
\hline At1g32928 & Unknown & & & & \\
\hline At1g72430 & Small auxin up-regulated RNA (SAUR 78) & & & & \\
\hline At1g72910 & Defense response; signal transduction & & & & \\
\hline At1g74450 & Response to chitin, wounding & & & & \\
\hline At1g74670 & Gibberellin-regulated f.p. & & & & \\
\hline At2g10940 & Lipid binding and transport & & & & \\
\hline At2g15960 & Unknown & & & & \\
\hline At2g23120 & Late embryogenesis abundant protein group 6; stress response & & & & \\
\hline At2g30020 & Defense and abscisic acid signaling pathway; mature pollen stages & & & & \\
\hline At2g41090 & Calcium ion binding, signaling & & & & \\
\hline At2g43530 & Defensin-like f.p. & & & & \\
\hline At3g15450 & Aluminum induced protein with YGL & & & & \\
\hline At3g19030 & Positive regulation of flavonoid biosynthetic processes & & & & \\
\hline At3g22235 & Unknown & & & & \\
\hline At3g28220 & Regulation of anthocyanin biosynthetic process & & & & \\
\hline At3g46620 & $\begin{array}{l}\text { Encodes ABA and drought-induced RING-DUF1117; defense } \\
\text { response }\end{array}$ & & & & \\
\hline At3g48740 & $\begin{array}{l}\text { Encodes member of the SWEET sucrose efflux transporter f.p; } \\
\text { cation homeostasis }\end{array}$ & & & & \\
\hline At3g57450 & Unknown; defense response & & & & \\
\hline At3g61260 & Remorin f.p.-binding & & & & \\
\hline At3g63160 & Cell differentiation, leaf morphogenesis; transcription & & & & \\
\hline At4g05150 & $\begin{array}{l}\text { Octicosapeptide/Phox/Bem1p; protein autophosphorylation; root } \\
\text { hair elongation }\end{array}$ & & & & \\
\hline At4g27280 & Calcium ion binding; stress (wounding) & & & & \\
\hline At4g27652 & Unknown & & & & \\
\hline At4g27657 & Unknown & & & & \\
\hline At4g29780 & Defense response & & & & \\
\hline At5g02160 & Cell differentiation; cation homeostasis & & & & \\
\hline At5g10860 & $\begin{array}{l}\text { Cystathionine beta-synthase domain-containing protein; } \\
\text { Modulates development by regulating thioredoxin system }\end{array}$ & & & & \\
\hline
\end{tabular}




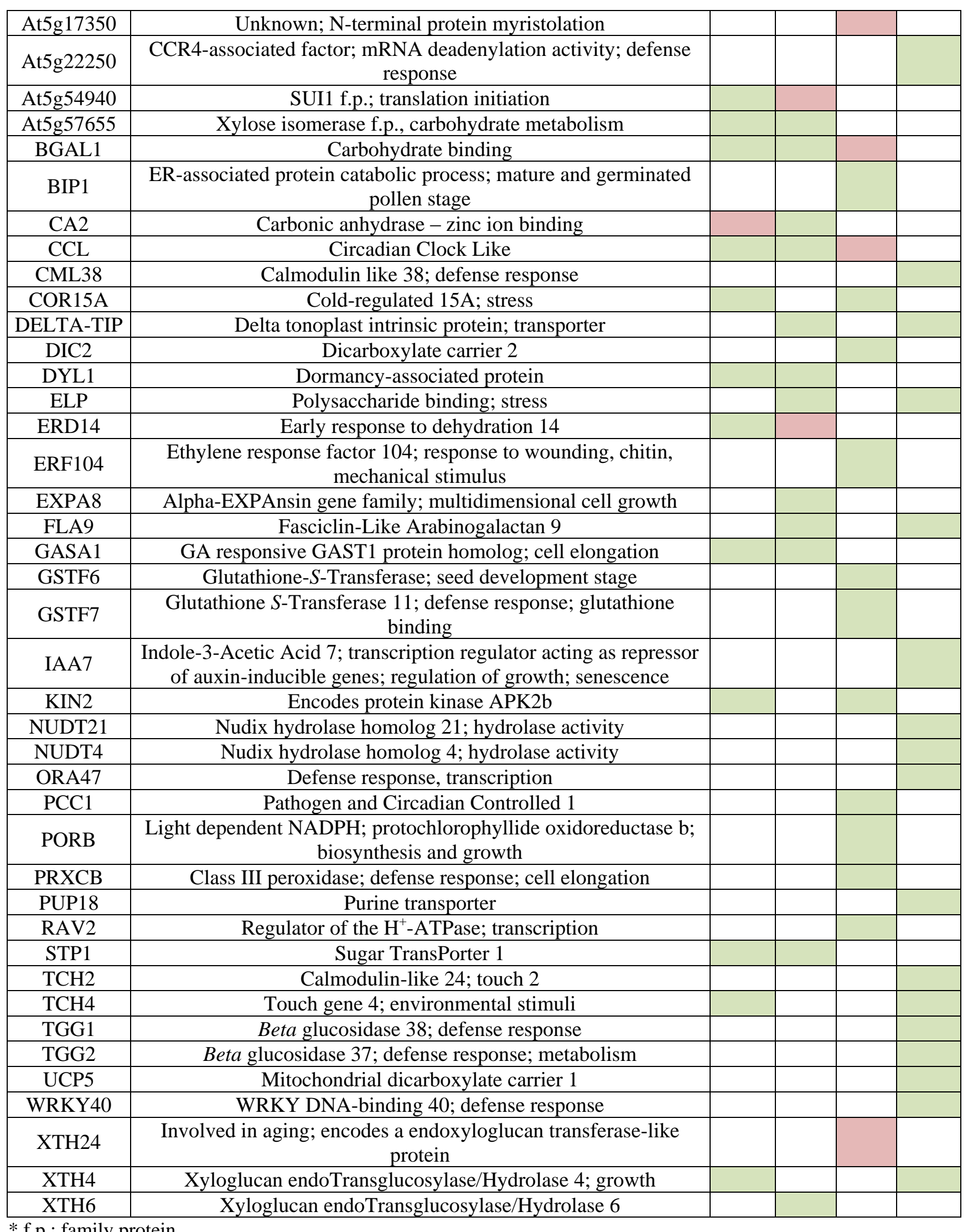


Table 5. TAIR GO biological functional annotation for all genes identified in the $\mathrm{Li}^{+}$-treated plants that were grown in soil that met the $p$-value of $\leq 0.05$. Whole genome information from TAIR is provided for reference.

\begin{tabular}{|c|c|c|c|c|c|c|}
\hline Biological Function & $\begin{array}{c}\text { Whole } \\
\text { Genome } \\
\text { N=24621 }\end{array}$ & \begin{tabular}{|c|} 
Wk 1 (\%) \\
N=1375; \\
Gene IDs: \\
$2748 ;$ \\
FPKM*: \\
146962 \\
\end{tabular} & $\begin{array}{c}\text { Wk 2 (\%) } \\
\text { N=1378; } \\
\text { Gene IDs: } \\
\text { 2753; } \\
\text { FPKM: } \\
\text { 293070 } \\
\end{array}$ & $\begin{array}{c}\text { Wk 3 (\%) } \\
\text { N=1400; } \\
\text { Gene IDs: } \\
\text { 2824; } \\
\text { FPKM: } \\
116698 \\
\end{array}$ & $\begin{array}{c}\text { Wk } 4(\%) \\
\text { N=422; } \\
\text { Gene IDs: } \\
\text { 936; } \\
\text { FPKM: } \\
\text { 29098 }\end{array}$ & \begin{tabular}{|c} 
Wk 5 (\%) \\
N=422; \\
Gene IDs: \\
936; \\
FPKM: \\
32014
\end{tabular} \\
\hline Cell organization and biogenesis & 13.6 & 12.1 & 12.0 & 8.4 & 8.5 & 8.5 \\
\hline Developmental processes & 15.6 & 10.5 & 10.4 & 8.4 & 10.7 & 10.7 \\
\hline DNA or RNA metabolism & 3.7 & 1.5 & 1.5 & 3.4 & 0.9 & 0.9 \\
\hline Electron transport or energy pathways & 2.8 & 4.4 & 4.4 & 1.4 & 1.6 & 1.6 \\
\hline Other biological processes & 14.8 & 14.2 & 12.3 & 18.1 & 18.9 & 18.9 \\
\hline Other cellular processes & 56.7 & 55.6 & 55.5 & 54.3 & 53.1 & 53.1 \\
\hline Other metabolic processes & 53.6 & 55.5 & 55.4 & 53.9 & 52.4 & 52.4 \\
\hline Protein metabolism & 21.3 & 18.2 & 18.2 & 22.1 & 17.3 & 17.3 \\
\hline Response to abiotic or biotic stimulus & 15.3 & 14.7 & 14.7 & 17.3 & 23.7 & 23.7 \\
\hline Response to stress & 16.6 & 15.9 & 15.9 & 19.3 & 24.9 & 24.9 \\
\hline Signal transduction & 8.1 & 6.4 & 6.4 & 9.8 & 12.8 & 12.8 \\
\hline Transcription, DNA-dependent & 10.6 & 6.8 & 6.7 & 6.4 & 4.5 & 4.5 \\
\hline Transport & 14.3 & 16.4 & 16.3 & 13.4 & 17.8 & 17.8 \\
\hline Unknown biological function & 32.9 & 38.8 & 38.7 & 37.8 & 35.3 & 35.3 \\
\hline
\end{tabular}

* FPKM: Sum of Fragments Per Kilobase of transcript per Million mapped reads. 
Table 6. Up- or down-regulation of the 56 most abundant genes found in more than two consecutive-wk comparisons of plant growth for the $0.05 \mathrm{mM} \mathrm{Li}^{+}$-treated soil-grown plants. These genes were selected from a pool of the top 100 genes by transcript abundance that met the $p$-value value requirement of $\leq 0.05$.

\begin{tabular}{|c|c|c|c|c|c|}
\hline $\begin{array}{l}\text { Accession } \\
\quad \text { No. }\end{array}$ & Gene Name; Function* & $\begin{array}{l}\text { Wk } 1 \\
\text { to } 2\end{array}$ & $\begin{array}{l}\text { Wk } 2 \\
\text { to } 3\end{array}$ & $\begin{array}{c}\text { Wk } 3 \\
\text { to } 4\end{array}$ & $\begin{array}{l}\text { Wk } 4 \\
\text { to } 5\end{array}$ \\
\hline AGP12 & Arabinogalactan protein 12 ; cell signaling & & & & \\
\hline AGP21 & Arabinogalactan protein 21 ; cell signaling & & & & \\
\hline At1g21500 & Unknown & & & & \\
\hline At1g29660 & GDSL-like lipase/acylhydrolase sf.p; defense response & & & & \\
\hline At1g52190 & Nitrate transporter & & & & \\
\hline At1g61740 & Sulfite exporter TauE/SafE f.p. & & & & \\
\hline At1g62480 & Vacuolar calcium-binding protein related; defense response & & & & \\
\hline At1g66760 & MATE efflux f.p.; transporter and antiporter activity & & & & \\
\hline At1g74470 & Geranylgeranyl reductase activity; photosynthesis & & & & \\
\hline At1g74670 & Gibberellin-regulated f.p. & & & & \\
\hline At2g10940 & 2S albumin sf.p & & & & \\
\hline At2g15960 & Unknown & & & & \\
\hline At3g06750 & Hydroxyproline-rich glycoprotein f.p.; cell signaling & & & & \\
\hline At3g08030 & Chlorophyll biosynthetic process; cell signaling & & & & \\
\hline At3g16370 & GDSL-like lipase/alcylhydrolase sf.p & & & & \\
\hline At3g22060 & Contains Pfam profile: PF01657 domain; defense response & & & & \\
\hline At3g22235 & Unknown & & & & \\
\hline At3g63160 & Outer Envelope Protein 6 (OEP6); growth and transcription & & & & \\
\hline At4g16980 & Arabinoglactan-protein family; photosynthesis, defense response & & & & \\
\hline At5g08330 & TCP family transcription factor & & & & \\
\hline At5g11420 & Unknown & & & & \\
\hline At5g16030 & Unknown & & & & \\
\hline At5g22580 & Stress responsive A/B barrel domain & & & & \\
\hline At5g25460 & DUF642 L-GALL responsive gene 2; root morphogenesis & & & & \\
\hline At5g39670 & Calcium-binding EF-hand-f.p. & & & & \\
\hline At5g44020 & HAD superfamily, subfamily IIIB acid phosphatase & & & & \\
\hline At5g51190 & $\begin{array}{l}\text { Ethylene Response Factor (ERF) subfamily B-3/AP2 transcription } \\
\text { factor family }\end{array}$ & & & & \\
\hline At5g51720 & NEET group protein & & & & \\
\hline At5g52760 & Copper transport protein family & & & & \\
\hline CCL & Involved in cellular cation homeostasis; divalent metal ion transport & & & & \\
\hline COR15A & Cold-regulated $15 \mathrm{~A} ;$ defense response & & & & \\
\hline COR15B & Cold-regulated 15B; defense response & & & & \\
\hline COR413IM1 & Cold regulated 314 inner membrane 1 & & & & \\
\hline DELTA-TIP & Delta tonoplast intrinsic protein; transporter & & & & \\
\hline DYL1 & Dormancy-associated protein 1 ; defense response & & & & \\
\hline ECS1 & Encodes cell wall protein; defense response & & & & \\
\hline ELP & Chitinase-like protein 1; growth & & & & \\
\hline ERF104 & Ethylene response factor 104 & & & & \\
\hline EXPA1 & Alpha-expansin gene family & & & & \\
\hline FLA9 & Fasciclin-Like Arabinogalactan 9 & & & & \\
\hline $\begin{array}{l}\text { GAMMA- } \\
\text { VPE }\end{array}$ & $\begin{array}{l}\text { Gamma vacuolar processing enzyme; response to toxin-induced cell } \\
\text { death }\end{array}$ & & & & \\
\hline
\end{tabular}




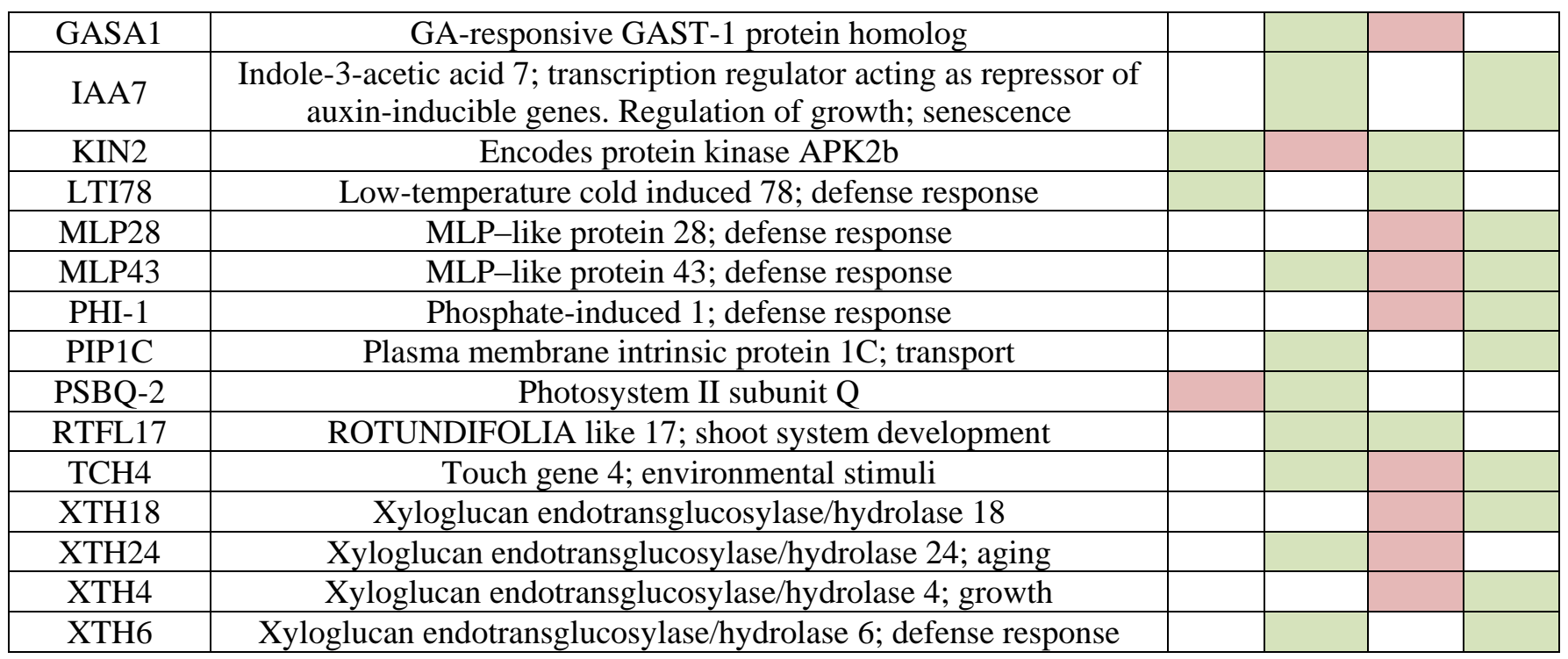

*sf.p.: superfamily protein; f.p.: family protein. 
Table 7. Listing of several genes that were highly regulated in the HP studies that met the $p$-value of $\leq 0.05$.

\begin{tabular}{|c|c|}
\hline Accession No. & Gene Name* \\
\hline At4g39800 & Inositol-3-phosphate synthase isozyme 1, MIPS1 \\
\hline At2g22240 & Inositol-3-phosphate synthase isozyme 2, MIPS2 \\
\hline At5g54390 & Inositol monophosphate f.p. \\
\hline At5g10170 & Inositol-3-phosphate synthase putative (put.) \\
\hline At5g09290, At5g63990 & $\begin{array}{l}\text { 3'(2'),5'-bisphosphate nucleotidase/inositol polyphosphate 1- } \\
\text { phosphatase }\end{array}$ \\
\hline At5g64000 & $\begin{array}{c}\text { 3'(2'),5'-bisphosphate nucleotidase/inositol polyphosphate 1- } \\
\text { phosphatase (SAL2) }\end{array}$ \\
\hline At2g43510 & Trypsin inhibitor put., TI1 \\
\hline At2g22810 & 1-aminocyclopropane-1-carboxylate synthase 4, ACS4 \\
\hline At4g26200 & 1-aminocyclopropane-1-carboxylate synthase 7, ACS7 \\
\hline At1g12010 & 1-aminocyclopropane-1-carboxylate oxidase, put. \\
\hline At5g24240, At3g56600 & Phosphatidylinositol (PI) 3- and 4-kinase f.p./ubiquitin protein \\
\hline At1g21980 & 1-PhosphatidylInositol-4-Phosphate 5-kinase, put. (PIP) kinase, put. \\
\hline At1g17860, At1g73260 & Trypsin and protease inhibitor protein \\
\hline $\begin{array}{l}\text { At1g55780, At2g35730, At3g04900, At3g07600, } \\
\text { At4g05030, At5g52720, At5g52740, At5g52760 }\end{array}$ & Heavy-metal-associated domain (HMAP)-containing protein \\
\hline At5g52770 & HMAP-related \\
\hline At1g22990 & HMAP-related/copper chaperone $(\mathrm{CCH})$ related \\
\hline At1g17020, At3g13610, At4g10500, At4g54000 & Oxidoreductase, 2OG-Fe(II) oxygenase f.p \\
\hline At1g33880, Atlg33950, At1g33930 & Avirulence-responsive f.p, avirulence induced gene (AIG1) f.p. \\
\hline At1g33960 & AIG1 \\
\hline At1g05680 & UDP-glucosyl transferase f.p. (UGT74E2) \\
\hline At1g22400 & UDP-glucosyl transferase f.p. (UGT85A1) \\
\hline At2g30140 & UDP-glucosyl transferase f.p. (UGT87A2) \\
\hline At2g43820 & UDP-glucosyl transferase f.p. (UGT74F2) \\
\hline At3g11340 & UDP-glucosyl transferase f.p. (UGT76B1) \\
\hline At3g46660 & UDP-glucosyl transferase f.p. (UGT76E12) \\
\hline At3g53150 & UDP-glucosyl transferase f.p. (UGT73D1) \\
\hline At4g15280 & UDP-glucosyl transferase f.p. (UGT71B5) \\
\hline At4g34135 & UDP-glucosyl transferase f.p. (UGT73B2) \\
\hline At4g34138 & UDP-glucosyl transferase f.p. (UGT73B1) \\
\hline $\begin{array}{c}\text { At1g01390, At2g36770, At3g46650, At3g46690, } \\
\text { At4g15260, At5g17040, At5g49690, At2g36970, } \\
\text { At3g02100 }\end{array}$ & UDP-glucosyl transferase f.p \\
\hline At1g53680 & Glutathione S-Transferase 28 (GSTU28) \\
\hline At1g69930 & GSTU11 \\
\hline At1g74590 & GSTU10 \\
\hline At3g09270 & GSTU8 \\
\hline At1g02820 & Late Embryogenesis Abundant 3 f.p. (LEA3) \\
\hline At5g06760 & LEA4-5 \\
\hline At1g52690 & LEA7 \\
\hline At2g35300 & LEA18 \\
\hline At2g03850 & LEA domain-containing protein \\
\hline At3g22500 & LEA protein (ECP31) \\
\hline At3g15670, At3g53040, At2g46140 & LEA domain-containing protein, put. \\
\hline At2g44240 & $\begin{array}{c}\text { Glycine-rich protein } 23 \text { (GRP23); induced by 16-hydroxypalmitic } \\
\text { acid (HPA) }\end{array}$ \\
\hline $\begin{array}{c}\text { At3g28510, At3g28540, At3g28580, At5g17760, } \\
\text { At5g40010 }\end{array}$ & AAA-type ATPase f.p. \\
\hline
\end{tabular}




\begin{tabular}{|c|c|}
\hline At1g15520 & ABC transporter f.p., Pleiotropic Drug Resistance 12 (PDR12) \\
\hline At2g39350, At3g53510, At4g18050 & ABC transporter f.p. \\
\hline At3g22910 & $\mathrm{Ca}^{2+}$-transporting ATPase, plasma membrane-type, putative \\
\hline At3g21180 & $\mathrm{Ca}^{2+}$-transporting ATPase, plasma membrane-type, putative \\
\hline At1g73800, At1g73805 & Calmodulin-binding protein \\
\hline At5g26920 & Calmodulin-binding 60-like-G (CBP60G) protein \\
\hline At3g22930 & Calmodulin-like 11 (CML11) protein \\
\hline At5g42380 & Calmodulin-8 (CAM8) \\
\hline At4g14640 & Germin-like protein (GLP9) \\
\hline At4g14630 & Peroxidase 27 (PER17) \\
\hline At2g22420 & PER27 \\
\hline At3g01190 & PER50 \\
\hline At4g37530 & PER37 \\
\hline At4g08770 & PER53 \\
\hline At5g06720 & PER52 \\
\hline At5g05340 & Peroxidase super f.p. \\
\hline At5g06730, At5g19880 & Plant invertase/pectin methylesterase inhibitor f.p. \\
\hline At2g47340 & Plant invertase/pectin methylesterase inhibitor sf.p. \\
\hline At1g11590, At5g20860 & Invertase/pectin methylesterase inhibitor f.p. \\
\hline At1g48010 & Pectin lyase-like f,p. \\
\hline At3g09540 & Pectinesterase f.p./ Pectin lyase-like sf.p. \\
\hline At5g07410 & Pectin lyase f,p. \\
\hline At1g14420 & Pectinesterase f.p. (PME17) \\
\hline At2g45220 & Pectinesterase f.p. (PME3) \\
\hline At3g14310 & \\
\hline At4g26530 & At fructose-bisphosphate aldolase 5 (AtFBA5) (requires Mg ${ }^{2+}$ ) \\
\hline At436430
\end{tabular}

* f.p.: family protein, sf,p.: superfamily protein. 
Table 8. Calculated fold-change and associated $t$-test $p$-values for the $\mathrm{HP} 1 \mathrm{mM} \mathrm{LiCl}, 1 \mathrm{mM} \mathrm{NaCl}$ and control exposures for MIPS, ACS, PR, heavy metal and AIG1 genes.

\begin{tabular}{|c|c|c|c|c|c|c|}
\hline Accession No.* & & & Fold-cha & nge $^{* * *}$ & & \\
\hline & $\begin{array}{l}\text { 1-d } 1 \mathrm{mM} \mathrm{Li}^{+} \\
\text {vs. Control }\end{array}$ & $\begin{array}{c}\text { 1-d } 1 \mathrm{mM} \mathrm{Li}^{+} \\
\text {vs. } \mathrm{Na}\end{array}$ & $\begin{array}{c}1-\mathrm{d} 1 \mathrm{mM} \\
\mathrm{Na}^{+} \text {vs. Control }\end{array}$ & \begin{tabular}{|c} 
7-d $1 \mathrm{mM} \mathrm{Li}^{+}$ \\
vs. Control
\end{tabular} & $\begin{array}{c}\text { 7-d } 1 \mathrm{mM} \mathrm{Li}^{+} \\
\text {vs. } \mathrm{Na}^{+}\end{array}$ & $\begin{array}{c}\text { 7-d } 1 \mathrm{mM} \\
\mathrm{Na}^{+} / \text {Control }\end{array}$ \\
\hline MIPS1 & BD & BD & BD & BD & $-2.94 ; p=0.001$ & BD \\
\hline MIPS2 & $1.52 ; p=0.018$ & $\mathrm{BD}$ & $\mathrm{BD}$ & $\mathrm{BD}$ & $-2.08 ; p=0.033$ & $\mathrm{BD}$ \\
\hline At5g54390 & $\mathrm{BD}$ & $\mathrm{BD}$ & $\mathrm{BD}$ & $\mathrm{BD}$ & $-1.61, p=0.001$ & $\mathrm{BD}$ \\
\hline At5g10170 & $\mathrm{BD}$ & $\mathrm{BD}$ & $\mathrm{BD}$ & $\mathrm{BD}$ & $-2.01 ; p=0.011$ & $\mathrm{BD}$ \\
\hline At5g09290 & $\mathrm{BD}$ & $\mathrm{BD}$ & BD & $\mathrm{BD}$ & $2.78 ; p=0.029$ & $\mathrm{BD}$ \\
\hline At5g63990 & $\mathrm{BD}$ & $\mathrm{BD}$ & $\mathrm{BD}$ & $\mathrm{BD}$ & $1.86: p=0.006$ & $\mathrm{BD}$ \\
\hline SAL2 & $\mathrm{BD}$ & $\mathrm{BD}$ & $\mathrm{BD}$ & $\mathrm{BD}$ & $3.69 ; p=0.045$ & $\mathrm{BD}$ \\
\hline TI1 & $2.31 ; p=0.002$ & $\mathrm{BD}$ & $\mathrm{BD}$ & $3.82 ; p=0.042$ & $3.29 ; p=0.051$ & $\mathrm{BD}$ \\
\hline ACS4 & $\mathrm{BD}$ & $\mathrm{BD}$ & $\mathrm{BD}$ & $\mathrm{BD}$ & $-1.58 ; p=0.038$ & $\mathrm{BD}$ \\
\hline ACS7 & $\mathrm{BD}$ & $\mathrm{BD}$ & $\mathrm{BD}$ & $\mathrm{BD}$ & $3.17 ; p=0.016$ & $\mathrm{BD}$ \\
\hline At1g12010 & $\mathrm{BD}$ & $\mathrm{BD}$ & $\mathrm{BD}$ & $\mathrm{BD}$ & $-3.41 ; p=0.017$ & $\mathrm{BD}$ \\
\hline At5g24240 & $\mathrm{BD}$ & $\mathrm{BD}$ & $\mathrm{BD}$ & $\mathrm{BD}$ & $7.29 ; p=0.021$ & $\mathrm{BD}$ \\
\hline At3g56600 & $\mathrm{BD}$ & $-2.24 ; p=0.037$ & $1.80 ; p=0.042$ & $\mathrm{BD}$ & BD & $\mathrm{BD}$ \\
\hline At1g21980 & $\mathrm{BD}$ & $\mathrm{BD}$ & $\mathrm{BD}$ & $\mathrm{BD}$ & $-1.79 ; p=0.007$ & \\
\hline At1g17860 & $\mathrm{BD}$ & $\mathrm{BD}$ & $\mathrm{BD}$ & $\mathrm{BD}$ & $1.54 ; p=0.013$ & $\mathrm{BD}$ \\
\hline At1g73260 & $\mathrm{BD}$ & $\mathrm{BD}$ & $\mathrm{BD}$ & $\mathrm{BD}$ & $3.89 ; p=0.037$ & $\mathrm{BD}$ \\
\hline PR1 & $\mathrm{BD}$ & $3.06 ; p=0.052$ & $\mathrm{BD}$ & $6.36 ; p=0.013$ & $5.98 ; p=0.019$ & $\mathrm{BD}$ \\
\hline PR p. At2g 14580 & $\mathrm{BD}$ & $\mathrm{BD}$ & $\mathrm{BD}$ & $4.30 ; p=0.044$ & $\mathrm{BD}$ & $\mathrm{BD}$ \\
\hline PR p. At4g31470 & $\mathrm{BD}$ & $1.91 ; p=0.028$ & $-2.08 ; p=0.002$ & $\mathrm{BD}$ & $\mathrm{BD}$ & $\mathrm{BD}$ \\
\hline PR5 & $\mathrm{BD}$ & $\mathrm{BD}$ & BD & $4.16 ; p=0.050$ & $\mathrm{BD}$ & $\mathrm{BD}$ \\
\hline At3g04900 & $1.80 ; p=0.020$ & $\mathrm{BD}$ & $1.76 ; p=0.032$ & $\mathrm{BD}$ & $\mathrm{BD}$ & $\mathrm{BD}$ \\
\hline At1g55780 & $\mathrm{BD}$ & $\mathrm{BD}$ & $\mathrm{BD}$ & $\mathrm{BD}$ & $4.88 ; p=0.022$ & $\mathrm{BD}$ \\
\hline At2g35730 & $\mathrm{BD}$ & $\mathrm{BD}$ & $\mathrm{BD}$ & $\mathrm{BD}$ & $5.44 ; p=0.034$ & $\mathrm{BD}$ \\
\hline At3g07600 & $\mathrm{BD}$ & $\mathrm{BD}$ & $\mathrm{BD}$ & $\mathrm{BD}$ & $2.82 ; p=0.007$ & $\mathrm{BD}$ \\
\hline At4g05030 & $\mathrm{BD}$ & $\mathrm{BD}$ & $\mathrm{BD}$ & $\mathrm{BD}$ & $3.33 ; p=0.052$ & $\mathrm{BD}$ \\
\hline At4g25780 & $\mathrm{BD}$ & $\mathrm{BD}$ & $\mathrm{BD}$ & $\mathrm{BD}$ & $-2.37 ; p=0.052$ & $\mathrm{BD}$ \\
\hline At5g52720 & $\mathrm{BD}$ & $\mathrm{BD}$ & $\mathrm{BD}$ & $\mathrm{BD}$ & $5.26 ; p<0.000$ & $\mathrm{BD}$ \\
\hline At5g52740 & $\mathrm{BD}$ & $\mathrm{BD}$ & $\mathrm{BD}$ & $3.98 ; p=0.013$ & $\mathrm{BD}$ & $2.63 ; p=0.013$ \\
\hline At5g52760 & $\mathrm{BD}$ & $\mathrm{BD}$ & BD & $\mathrm{BD}$ & $1.89 ; p=0.039$ & $\mathrm{BD}$ \\
\hline At5g52770 & $\mathrm{BD}$ & $\mathrm{BD}$ & $\mathrm{BD}$ & $\mathrm{BD}$ & $3.10 ; p=0.041$ & $\mathrm{BD}$ \\
\hline At1g22990 & $\mathrm{BD}$ & $\mathrm{BD}$ & $\mathrm{BD}$ & $\mathrm{BD}$ & $5.45 ; p=0.016$ & $\mathrm{BD}$ \\
\hline At4g10500 & $\mathrm{BD}$ & $\mathrm{BD}$ & $\mathrm{BD}$ & $\mathrm{BD}$ & $5.79 ; p=0.022$ & $\mathrm{BD}$ \\
\hline At1g33870 & $\mathrm{BD}$ & $3.04 ; p=0.023$ & $\mathrm{BD}$ & $\mathrm{BD}$ & $\mathrm{BD}$ & $\mathrm{BD}$ \\
\hline At1g33880 & $\mathrm{BD}$ & $2.44 ; p=0.012$ & $\mathrm{BD}$ & $\mathrm{BD}$ & $\mathrm{BD}$ & $\mathrm{BD}$ \\
\hline At1g33930 & $\mathrm{BD}$ & $\mathrm{BD}$ & $\mathrm{BD}$ & $\mathrm{BD}$ & $\mathrm{BD}$ & $-2.31 ; p=0.009$ \\
\hline At1g33950 & $\mathrm{BD}$ & $\mathrm{BD}$ & $\mathrm{BD}$ & $\mathrm{BD}$ & $2.58 ; p=0.054$ & $\mathrm{BD}$ \\
\hline AIG1 At1g33960 & $\mathrm{BD}$ & $\mathrm{BD}$ & $\mathrm{BD}$ & $6.93 ; p=0.025$ & $\mathrm{BD}$ & $3.35 ; p=0.025$ \\
\hline At1g33930 & $\mathrm{BD}$ & $\mathrm{BD}$ & $\mathrm{BD}$ & $-2.81 ; p=0.009$ & $\mathrm{BD}$ & $-2.31 ; p=0.009$ \\
\hline At2g44240 & $\mathrm{BD}$ & $\mathrm{BD}$ & $\mathrm{BD}$ & $7.83 ; p=0.010$ & $8.99 ; p=0.005$ & $\mathrm{BD}$ \\
\hline
\end{tabular}

*p: putative; f.p.: family protein.

**BD: Below Detection. This is based on the fold-change cut-off of \pm 1.5 and a $p$-value of $\leq 0.05$ for MA data. 
Table 9. Calculated fold-change and associated t-test $p$-values for the $\mathrm{HP} 1 \mathrm{mM} \mathrm{LiCl}, 1 \mathrm{mM} \mathrm{NaCl}$ and control exposures for UGT and LEA series genes.

\begin{tabular}{|c|c|c|c|c|c|c|}
\hline \multirow[t]{2}{*}{ Accession No.* } & \multicolumn{6}{|c|}{ Fold-change** } \\
\hline & $\begin{array}{l}1 \text { 1-d } 1 \mathrm{mM} \mathrm{Li}^{+} \\
\text {vs. Control }\end{array}$ & $\begin{array}{c}1-\mathrm{d} 1 \mathrm{mM} \mathrm{Li}^{+} \text {vs. } \\
\mathrm{Na}\end{array}$ & $\begin{array}{c}1-\mathrm{d} 1 \mathrm{mM} \\
\mathrm{Na}^{+} \text {vs. Control }\end{array}$ & $\begin{array}{c}\text { 7-d } 1 \mathrm{mM} \mathrm{Li}^{+} \\
\text {vs. Control }\end{array}$ & $\begin{array}{c}\text { 7-d } 1 \mathrm{mM} \mathrm{Li}^{+} \\
\text {vs. } \mathrm{Na}^{+}\end{array}$ & $\begin{array}{c}\text { 7-d } 1 \mathrm{mM} \\
\mathrm{Na}^{+} / \text {Control }\end{array}$ \\
\hline UGT74E2 & $\mathrm{BD}$ & BD & BD & $2.72 ; p=0.003$ & $3.44 ; p=0.034$ & BD \\
\hline UGT87A2 & $\mathrm{BD}$ & $\mathrm{BD}$ & $\mathrm{BD}$ & $\mathrm{BD}$ & $1.82 ; p=0.035$ & $\mathrm{BD}$ \\
\hline UGT f.p. At2g36770 & BD & BD & BD & BD & $1.68 ; p=0.010$ & BD \\
\hline UGT76B1 & $\mathrm{BD}$ & $\mathrm{BD}$ & BD & $\mathrm{BD}$ & $3.61 ; p=0.052$ & $\mathrm{BD}$ \\
\hline UGT f.p. At3g46690 & $\mathrm{BD}$ & $\mathrm{BD}$ & BD & $\mathrm{BD}$ & $2.78 ; p=0.011$ & $\mathrm{BD}$ \\
\hline UGT73D1 & $\mathrm{BD}$ & BD & BD & $\mathrm{BD}$ & $6.02 ; p=0.008$ & $\mathrm{BD}$ \\
\hline UGT73B1 & $\mathrm{BD}$ & $\mathrm{BD}$ & BD & $\mathrm{BD}$ & $1.64 ; p=0.021$ & \\
\hline UGT73B2 & $\mathrm{BD}$ & $2.75 ; p=0.011$ & $\mathrm{BD}$ & $\mathrm{BD}$ & $3.51 ; p=0.005$ & $\mathrm{BD}$ \\
\hline UGT85A1 & $\mathrm{BD}$ & BD & $\mathrm{BD}$ & $2.43 ; p=0.030$ & BD & $\mathrm{BD}$ \\
\hline UGT f.p. At5g49690 & $\mathrm{BD}$ & $\mathrm{BD}$ & $\mathrm{BD}$ & $2.76 ; p=0.017$ & $\mathrm{BD}$ & $\mathrm{BD}$ \\
\hline UGT76E12 & $3.28 ; p=0.031$ & $\mathrm{BD}$ & $\mathrm{BD}$ & BD & $\mathrm{BD}$ & $\mathrm{BD}$ \\
\hline UGT74F2 & $1.66 ; p=0.004$ & $\mathrm{BD}$ & $\mathrm{BD}$ & $\mathrm{BD}$ & BD & BD \\
\hline UGT f.p. At3g46650 & $-2.19 ; p=0.028$ & $-2.58 ; p=0.024$ & $\mathrm{BD}$ & $\mathrm{BD}$ & $\mathrm{BD}$ & $\mathrm{BD}$ \\
\hline UGT f.p. At5g17040 & BD & BD & $\mathrm{BD}$ & $\mathrm{BD}$ & $-2.31 ; p=0.011$ & $\mathrm{BD}$ \\
\hline UGT f.p. At1g01390 & $\mathrm{BD}$ & $\mathrm{BD}$ & $\mathrm{BD}$ & $\mathrm{BD}$ & $-2.28 ; p=0.044$ & $\mathrm{BD}$ \\
\hline UGT f.p. At4g15260 & $\mathrm{BD}$ & $\mathrm{BD}$ & $3.27 ; p=0.037$ & $\mathrm{BD}$ & $\mathrm{BD}$ & $\mathrm{BD}$ \\
\hline UGT71B5 & $\mathrm{BD}$ & $\mathrm{BD}$ & $1.51 ; p=0.044$ & $\mathrm{BD}$ & $\mathrm{BD}$ & BD \\
\hline UGT f.p. At2g36970 & $\mathrm{BD}$ & $\mathrm{BD}$ & BD & $1.81 ; p=0.040$ & $\mathrm{BD}$ & $2.51 ; p=0.040$ \\
\hline UGT f.p. At3g02100 & $3.05 ; p=0.015$ & & $3.66 ; p=0.026$ & BD & $\mathrm{BD}$ & $\mathrm{BD}$ \\
\hline GSTU28 & BD & $\mathrm{BD}$ & BD & $\mathrm{BD}$ & $1.51 ; p=0.024$ & $\mathrm{BD}$ \\
\hline GSTU11 & BD & BD & $\mathrm{BD}$ & $\mathrm{BD}$ & $5.15 ; p=0.029$ & BD \\
\hline GSTU10 & $\mathrm{BD}$ & $\mathrm{BD}$ & $\mathrm{BD}$ & $\mathrm{BD}$ & $4.99 ; p=0.019$ & $\mathrm{BD}$ \\
\hline GSTU8 & $\mathrm{BD}$ & $\mathrm{BD}$ & $\mathrm{BD}$ & $\mathrm{BD}$ & $5.91 ; p=0.004$ & BD \\
\hline LEA3 & $\mathrm{BD}$ & $2.67 ; p=0.037$ & $\mathrm{BD}$ & $3.99 ; p=0.010$ & BD & $3.51 ; p=0.010$ \\
\hline LEA f.p. At2g03850 & $\mathrm{BD}$ & $\mathrm{BD}$ & $\mathrm{BD}$ & $3.54 ; p=0.009$ & $4.40 ; p=0.022$ & $\mathrm{BD}$ \\
\hline LEA f.p. At3g15670 & $\mathrm{BD}$ & $\mathrm{BD}$ & $\mathrm{BD}$ & $3.21 ; p=0.023$ & $1.99 ; p=0.038$ & $\mathrm{BD}$ \\
\hline LEA f.p. At3g53040 & $\mathrm{BD}$ & $\mathrm{BD}$ & $\mathrm{BD}$ & $3.59 ; p=0.028$ & $4.34 ; p=0.050$ & $\mathrm{BD}$ \\
\hline LEA7 & $\mathrm{BD}$ & $\mathrm{BD}$ & $\mathrm{BD}$ & $\mathrm{BD}$ & $4.00 ; p=0.022$ & $\mathrm{BD}$ \\
\hline LEA f.p. At2g46140 & $\mathrm{BD}$ & $\mathrm{BD}$ & $\mathrm{BD}$ & $\mathrm{BD}$ & $1.55 ; p=0.015$ & $\mathrm{BD}$ \\
\hline LEA4-5 & BD & $\mathrm{BD}$ & $\mathrm{BD}$ & $\mathrm{BD}$ & $2.27 ; p=0.034$ & BD \\
\hline LEA18 & BD & BD & BD & BD & $4.79 ; p=0.048$ & BD \\
\hline ECP31 & $\mathrm{BD}$ & $\mathrm{BD}$ & $-2.11 ; p=0.037$ & BD & BD & $\mathrm{BD}$ \\
\hline
\end{tabular}

*p: putative; f.p.: family protein.

**BD: Below Detection. This is based on the fold-change cut-off of \pm 1.5 and a $p$-value of $\leq 0.05$ for MA data. 
Table 10. Calculated fold-change and associated t-test $p$-values for the $\mathrm{HP} 1 \mathrm{mM} \mathrm{LiCl}, 1 \mathrm{mM} \mathrm{NaCl}$ and control exposures for various proteins that were mostly up-regulated in the HP study.

\begin{tabular}{|c|c|c|c|c|c|c|}
\hline Accession No.* & & & Fold-chan & ge $^{* *}$ & & \\
\hline & $\begin{array}{c}\text { 1-d } 1 \mathrm{mM} \mathrm{Li}^{+} \mathrm{vs} . \\
\text { Control }\end{array}$ & $\begin{array}{c}\text { 1-d } 1 \mathrm{mM} \mathrm{Li}^{+} \text {vs. } \\
\mathrm{Na}\end{array}$ & $\begin{array}{c}1-\mathrm{d} 1 \mathrm{mM} \\
\mathrm{Na}^{+} \text {vs. Control }\end{array}$ & $\begin{array}{c}\text { 7-d } 1 \mathrm{mM} \mathrm{Li}^{+} \text {vs. } \\
\text { Control }\end{array}$ & 7-d $1 \mathrm{mM} \mathrm{Li}^{+}$vs. & $\begin{array}{c}\text { 7-d } 1 \mathrm{mM} \\
\mathrm{Na}^{+} / \text {Control }\end{array}$ \\
\hline GRP23 & $\mathrm{BD}$ & $\mathrm{BD}$ & $\mathrm{BD}$ & $7.89 ; p=0.010$ & $8.46 ; p=0.003$ & $\mathrm{BD}$ \\
\hline \begin{tabular}{|l|l} 
At3g28510 \\
\end{tabular} & $\mathrm{BD}$ & $\mathrm{BD}$ & $\mathrm{BD}$ & $\mathrm{BD}$ & $5.36 ; p=0.020$ & $\mathrm{BD}$ \\
\hline At3g28540 & BD & BD & BD & $3.56 ; p=0.044$ & BD & $2.38 ; p=0.044$ \\
\hline At3g28580 & BD & $\mathrm{BD}$ & $\mathrm{BD}$ & BD & $2.39 ; p=0.021$ & $\mathrm{BD}$ \\
\hline At5g17760 & BD & BD & $\mathrm{BD}$ & $\mathrm{BD}$ & $2.26 ; p=0.025$ & $\mathrm{BD}$ \\
\hline At5g40010 & $\mathrm{BD}$ & $\mathrm{BD}$ & $\mathrm{BD}$ & $\mathrm{BD}$ & $3.63 ; p=0.026$ & BD \\
\hline PDR12 & $\mathrm{BD}$ & $\mathrm{BD}$ & $\mathrm{BD}$ & BD & $4.01 ; p=0.029$ & $4.43 ; p=0.001$ \\
\hline At2g39350 & BD & BD & $\mathrm{BD}$ & $4.43 ; p=0.001$ & $1.82 ; p=0.009$ & BD \\
\hline At3g53510 & $1.64 ; p=0.004$ & BD & $2.11 ; p=0.037$ & BD & $1.93 ; p=0.045$ & BD \\
\hline At4g18050 & BD & BD & BD & BD & $1.65 ; p=0.004$ & BD \\
\hline At3g21180 & $-2.25 ; p=0.000$ & BD & BD & BD & BD & BD \\
\hline At3g22910 & BD & BD & BD & BD & $4.08 ; p=0.013$ & BD \\
\hline At1g73800 & BD & BD & BD & BD & $2.39 ; p=0.006$ & BD \\
\hline At1g73805 & BD & BD & BD & BD & $1.97 ; p=0.011$ & BD \\
\hline CBP60G & BD & BD & BD & BD & $1.94 ; p=0.001$ & BD \\
\hline CAM8 & BD & BD & BD & $2.50 ; p=0.048$ & $3.92 ; p=0.039$ & BD \\
\hline CML11 & BD & BD & BD & BD & $1.59 ; p=0.017$ & BD \\
\hline CML17 & BD & BD & BD & BD & $3.28 ; p=0.014$ & BD \\
\hline At1g67980 & BD & BD & BD & BD & $6.39 ; p=0.005$ & BD \\
\hline GLP9 & BD & BD & BD & BD & $9.00 ; p=0.005$ & BD \\
\hline PER17 & $1.95 ; p=0.024$ & BD & BD & BD & BD & BD \\
\hline PER27 & BD & BD & BD & BD & $1.97 ; p=0.029$ & BD \\
\hline PER50 & BD & BD & BD & BD & $2.61 ; p=0.007$ & BD \\
\hline PER37 & BD & BD & BD & BD & $4.91 ; p=0.008$ & BD \\
\hline PER53 & BD & BD & BD & BD & $3.49 ; p=0.0004$ & BD \\
\hline PER52 & $1.85 ; p=0.043$ & BD & $3.47 ; p=0.006$ & BD & BD & BD \\
\hline At4g36430 & $1.92 ; p=0.012$ & BD & $\mathrm{BD}$ & BD & $2.56 ; p=0.054$ & BD \\
\hline At5g06730 & $2.44 ; p=0.004$ & BD & BD & BD & $6.33 ; p=0.011$ & BD \\
\hline At5g19880 & $2.71 ; p=0.021$ & BD & BD & $5.79 ; p=0.013$ & $5.85 ; p=0.014$ & $\mathrm{BD}$ \\
\hline At2g47340 & $2.16 ; p=0.041$ & BD & BD & BD & $\mathrm{BD}$ & BD \\
\hline At3g 42570 & BD & BD & BD & BD & $-1.71 ; p=0.031$ & $\mathrm{BD}$ \\
\hline At1g11590 & BD & BD & BD & BD & $-4.42 ; p=0.023$ & $\mathrm{BD}$ \\
\hline At5g20860 & $-2.86 ; p=0.006$ & BD & BD & BD & BD & $\mathrm{BD}$ \\
\hline At1g48010 & BD & $\mathrm{BD}$ & $\mathrm{BD}$ & $-2.41 ; p=0.053$ & $\mathrm{BD}$ & $-1.56 ; p=0.053$ \\
\hline At3g09540 & $\mathrm{BD}$ & $\mathrm{BD}$ & $\mathrm{BD}$ & $\mathrm{BD}$ & $-1.71 ; p=0.004$ & $-1.92 ; p=0.031$ \\
\hline At5g07410 & $-2.93 ; p=0.005$ & $-1.58 ; p=0.039$ & BD & $2.25 ; p=0.038$ & BD & $3.14 ; p=0.038$ \\
\hline At1g14420 & $2.18 ; p=0.050$ & BD & $\mathrm{BD}$ & $\mathrm{BD}$ & BD & BD \\
\hline PME17 & $\mathrm{BD}$ & $\mathrm{BD}$ & $\mathrm{BD}$ & $\mathrm{BD}$ & $7.16 ; p=0.005$ & $\mathrm{BD}$ \\
\hline PME3 & BD & BD & BD & BD & $-4.42 ; p=0.023$ & BD \\
\hline AtFBA5 & BD & BD & BD & BD & $-2.31 ; p=0.019$ & BD \\
\hline
\end{tabular}

*p: putative; f.p.: family protein.

**BD: Below Detection. This is based on the fold-change cut-off of \pm 1.5 and a $p$-value of $\leq 0.05$ for MA data. 
Table 11. Average transcript abundance values for specific identified genes from the soil-based studies. Values represent genes that met the cut-off requirements on a wk to wk per treatment (control or $0.05 \mathrm{mM} \mathrm{Li}^{+}$) basis.

\begin{tabular}{|c|c|c|c|c|c|c|c|c|c|c|}
\hline $\begin{array}{c}\text { Accession } \\
\text { No. }\end{array}$ & $\begin{array}{l}\text { Wk } 1 \mathrm{Li}^{+}- \\
\text {treatment* }\end{array}$ & \begin{tabular}{|c|} 
Wk 1 \\
Control
\end{tabular} & $\begin{array}{l}\text { Wk } 2 \mathrm{Li}^{+}- \\
\text {treatment }\end{array}$ & \begin{tabular}{|c|} 
Wk 2 \\
Control
\end{tabular} & $\begin{array}{l}\text { Wk } 3 \mathrm{Li}^{+}- \\
\text {treatment }\end{array}$ & \begin{tabular}{|c|} 
Wk 3 \\
Control
\end{tabular} & $\begin{array}{l}\text { Wk } 4 \mathrm{Li}^{+}- \\
\text {treatment }\end{array}$ & \begin{tabular}{|c|} 
Wk 4 \\
Control
\end{tabular} & $\begin{array}{l}\text { Wk } 5 \mathrm{Li}^{+}- \\
\text {treatment }\end{array}$ & \begin{tabular}{|c|} 
Wk 5 \\
Control
\end{tabular} \\
\hline SAL2 & 5 & 1 & ND & 6 & 64 & ND & ND & ND & 2 & 38 \\
\hline At3g28580 & ND & ND & 4 & 4 & 56 & ND & ND & ND & ND & 22 \\
\hline AtFBA5 & ND & ND & ND & 45 & 148 & 49 & 155 & ND & ND & ND \\
\hline BGL2 & ND & ND & ND & ND & 4 & ND & 61 & 2 & 814 & 594 \\
\hline At4g10500 & ND & ND & ND & ND & ND & ND & 7 & ND & 78 & 29 \\
\hline SAG13 & 10 & ND & 1 & 1 & 3 & ND & 22 & 2 & 102 & 40 \\
\hline LURP1 & 5 & ND & 1 & ND & 6 & 9 & 28 & 1 & 331 & 189 \\
\hline PR1 & 20 & ND & ND & ND & ND & ND & 38 & ND & 313 & 125 \\
\hline PR4 & ND & 39 & 11 & 15 & 54 & ND & 23 & ND & 105 & ND \\
\hline PR5 & 21 & 3 & 3 & 2 & ND & ND & 38 & ND & 594 & 405 \\
\hline At5g52760 & ND & ND & 13 & 55 & 52 & ND & 138 & ND & 346 & ND \\
\hline AIG1 & ND & ND & ND & ND & 3 & ND & ND & ND & 52 & 31 \\
\hline AIG2 & ND & ND & 29 & 20 & 101 & 72 & 66 & 30 & 138 & ND \\
\hline CAB2 & 1226 & 2324 & 6812 & 7941 & ND & ND & ND & ND & ND & ND \\
\hline LHCB3 & 646 & 1310 & 5586 & 5043 & ND & ND & ND & ND & ND & ND \\
\hline PSAG & 1029 & 1741 & 4504 & 4657 & ND & ND & ND & ND & ND & ND \\
\hline
\end{tabular}

*NG: Not Detected. These NGS data did not meet the $p$-value cut-off of $\leq 0.05$. 